\title{
Hydrothermal alteration studies of gabbros from Northern Central Indian Ridge and their geodynamic implications
}

\author{
Dwijesh Ray ${ }^{1, *}$, Catherine Mevel ${ }^{2}$ and Ranadip Banerjee ${ }^{3}$ \\ ${ }^{1}$ National Centre for Antarctic 83 Ocean Research, Goa 403 804, India. \\ ${ }^{2}$ Geosciences Marines, CNRS, IPGP, 4 Place Jussieu, F-75252 Paris Cedex 5, France. \\ ${ }^{3}$ National Institute of Oceanography, Goa 403004 , India. \\ *e-mail:dwijesh@rediffmail.com
}

\begin{abstract}
Mylonitic gabbro and altered gabbro were recovered from off-axis high and corner high locations at ridge-transform intersection, adjacent to Vityaz transform fault of the slow spreading (32-35 mm/yr, full spreading) Northern Central Indian Ridge. Both the varieties show signatures of extensive alteration caused due to interaction with sea water. Mylonitic gabbro represents high temperature metamorphism $\left(\sim 700-800^{\circ} \mathrm{C}\right)$ and comprised of hornblende mineral which exhibits well defined foliation/gneissic appearance along with dynamically recrystallised plagioclase grains frequently intercalated with magnetite-ilmenite. Altered gabbro from corner high generally includes low temperature greenschist grade $\left(\sim 300^{\circ} \mathrm{C}\right)$ mineralogical assemblages: chlorite, albite, quartz and locally magnesio hornblende. Crystal plastic deformation resulted in mylonite formation and often porphyroclasts of plagioclase and clinopyroxene grains, while altered gabbro locally exhibits cataclastic texture. Presence of Vityaz transform fault and adjacent megamullion at the weakly magmatic ridge-transform intersection and off-axis high locations prompted the present scenario very much conducive for hydrothermal circulation and further facilitate the exhumation of present suite of gabbro.
\end{abstract}

\section{Introduction}

Detailed petrologic studies of oceanic gabbros have demonstrated that metamorphic recrystallisation is related either to deformation and/or prolonged circulation of fluid during the progressive cooling of the gabbroic sequence (Honnorez et al 1984; Mevel 1987, 1988; Stakes et al 1991; Alt and Bach 2001). Magmatism in association with faulting plays a crucial role to understand deformation processes, magma migration paths and chemical differentiation processes, while hydrothermal circulation caused the post-crystallisation mineralogical changes within gabbro. Detailed studies of petrography and mineral chemistry of mylonitic gabbro and altered gabbro from Northern Central Indian Ridge (NCIR) have been undertaken to trace the hydrothermal alteration process of lower oceanic crust at slow spreading ridges. Hydrothermally altered plutonic rock samples also provide information about both the primary igneous intrusions that supplied heat to drive hydrothermal circulation and the geochemical evolution of hydrothermal fluids during rock-fluid interaction. Thus, the alteration in layer 3 crustal section always provides rare opportunity to our understanding on hydrothermal processes at spreading ridge system.

Earlier studies on mineralogy and geochemistry of altered gabbro are mainly restricted with slow spreading MAR (ODP Leg 153, Agar and Lloyd 1997), fast spreading Hess Deep, EPR (Mevel and Stamoudi 1996) or ultraslow spreading SWIR (Hole 735B, Stakes et al 1991; Vanko and Stakes 1991; Alt and Bach 2001). In contrast, very less information on hydrothermal alteration of gabbro

Keywords. Mylonitic gabbro; altered gabbro; hydrothermal alteration; Northern Central Indian Ridge. 


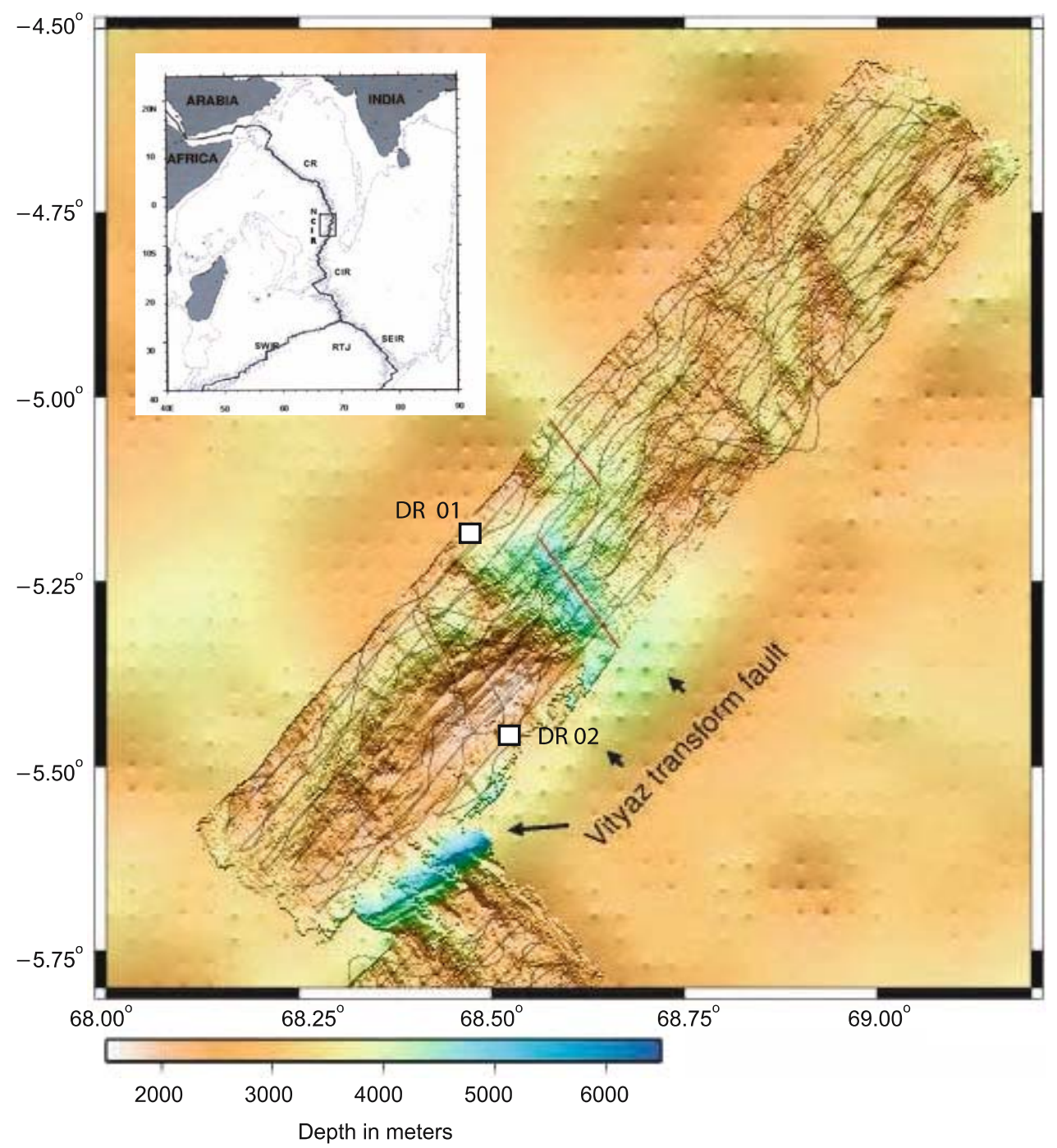

Figure 1. Map showing Vityaz megamullion and present gabbro locations (stations DR 01 and DR 02 respectively) along the Northern Central Indian Ridge (after Drolia and DeMets 2005). Inset map showing Indian Ocean Ridge System.

is available from NCIR - one of the least understood mid-ocean ridge system. Earlier reports on occurrences of gabbro from CIR were reported by Engel and Fisher in 1975, though the alteration characteristics of CIR gabbro were not discussed elsewhere. In order to characterize the extent of hydrothermal alteration in gabbros, we present the first report of petrography and mineral chemistry of the hydrothermally altered gabbros collected from NCIR (figure 1). The basic objective of this paper is to address the sequence and extent of alteration using texture, mineralogy and chemical compositional variations and also understand their geodynamic implications.

\section{Methodology}

Samples studied here were dredged using chain bag dredge from off-axis high and inside corner high (both the locations are adjacent to Vityaz 'megamullion') of Vityaz transform fault (TF) of slow-spreading NCIR (figure 1, Drolia and DeMets 2005). The full spreading rate of the present study area is $32-35 \mathrm{~mm} / \mathrm{yr}$ (DeMets et al 2005). The first location (DR $01 \sim 5^{\circ} 11.02^{\prime} \mathrm{S} / 68^{\circ} 28.10^{\prime} \mathrm{E}$, figure 1 ) was dredged from an off-axis high, northern side of active 'Vityaz megamullion' as described by Drolia and DeMets in 2005. Gabbros from this location include mainly mylonite gabbros. The second location (DR $02 \sim 5^{\circ} 26.92^{\prime} \mathrm{S} / 68^{\circ} 31.76^{\prime} \mathrm{E}$, figure 1) is on the southern side of 'megamullion' represents an inside corner high of Vityaz transform fault, vice versa flank of 'Kurchatov seamount' as described by Russian researchers during their expedition (Baturin and Rozanova 1975). Rocks dredged from this site are mainly altered gabbro underwent greenschist facies alteration.

Electron probe micro-analyses of primary as well as the secondary minerals were conducted using 
Table 1. Location, tectonic setting and brief petrographic descriptions of Northern Central Indian Ridge gabbros.

\begin{tabular}{|c|c|c|c|c|c|}
\hline $\begin{array}{l}\text { Station, } \\
\text { position } \\
\text { and depth }\end{array}$ & $\begin{array}{l}\text { Type of } \\
\text { gabbro }\end{array}$ & $\begin{array}{l}\text { Tectonic } \\
\text { setting }\end{array}$ & Petrography & $\begin{array}{c}\text { Mineralogy } \\
\text { (primary+secondary) }\end{array}$ & $\begin{array}{l}\text { Grade of } \\
\text { alteration }\end{array}$ \\
\hline $\begin{array}{l}\text { DR-01 } \\
5^{\circ} 11.02^{\prime} \mathrm{S} / \\
68^{\circ} 28.10^{\prime} \mathrm{E} \\
3000 \mathrm{~m}\end{array}$ & $\begin{array}{l}\text { Mylonitic } \\
\text { gabbro }\end{array}$ & Off-axis high & $\begin{array}{l}\text { Mostly exhibits } \\
\text { banded feature by } \\
\text { recrystallised plagio- } \\
\text { clase, amphibole and } \\
\text { Fe-Ti oxide, plagio- } \\
\text { clase and clinopyrox- } \\
\text { ene as porphyroclasts }\end{array}$ & $\begin{array}{l}\text { Plagioclase (anorthite+ } \\
\text { labradorite) } \sim 40 \% \\
\text { Clinopyroxene } \sim 10 \% \\
\text { Hornblende } \sim 20 \% \\
\text { Fe-Ti oxide } \sim 15 \% \\
\text { Chlorite } \sim 5 \% \\
\text { Epidote } \sim 5 \%\end{array}$ & $\begin{array}{l}\text { Mostly } \\
\text { amphibolite } \\
\text { facies, locally } \\
\text { greenschist } \\
\text { facies }\end{array}$ \\
\hline $\begin{array}{l}\text { DR-02 } \\
5^{\circ} 26.92^{\prime} \mathrm{S} / \\
68^{\circ} 31.76^{\prime} \mathrm{E} \\
2260 \mathrm{~m}\end{array}$ & $\begin{array}{l}\text { Altered } \\
\text { gabbro, } \\
\text { brecciated }\end{array}$ & $\begin{array}{l}\text { Corner high } \\
\text { of Vityaz TF }\end{array}$ & $\begin{array}{l}\text { Mostly comprised of } \\
\text { angular, brecciated } \\
\text { plagioclase. Albite, } \\
\text { chlorite and quartz } \\
\text { closely associated, } \\
\text { cataclasic texture }\end{array}$ & $\begin{array}{l}\text { Plagioclase (labradorite+ } \\
\text { albite) } \sim 60 \% \\
\text { Chlorite } \sim 10 \% \\
\text { Amphibole } \sim 10-15 \% \\
\text { Quartz } \sim 10-15 \%\end{array}$ & $\begin{array}{l}\text { Mainly green- } \\
\text { schist facies, } \\
\text { locally amphi- } \\
\text { bolite facies }\end{array}$ \\
\hline
\end{tabular}

both the Cameca SX 50 and SX 100 WDS electron microprobe analyzer at the CAMPARIS service of the IPG-Paris (University of Paris 6, France). Analytical conditions used were $15 \mathrm{kV}$ accelerating voltage, $20 \mathrm{nA}$ beam current and $20-40 \mathrm{~s}$ counting times. All analyses were performed in a point mode. A $2-3 \mu \mathrm{m}$ beam size was used for all minerals (plagioclase, amphibole, pyroxene, epidote). The obtained data were reduced using a ZAF and PAP correction procedure. Natural mineral standards were employed to check the precision and accuracy of the instrument (always better than 5\%).

\section{Results}

\subsection{Petrography}

Mylonite gabbro (mineralogical assemblages up to amphibolite facies) and altered gabbro (mineralogical assemblages up to greenschist facies), terminology were used on the basis of their texture as well as mineralogy and the petrographic observations (carefully chosen 20 samples on each location). Based on petrographic observations and presence and nature of secondary minerals, the samples are classified into two types: lowtemperature altered gabbro and high-temperature mylonite gabbro. The details of the microscopic characteristics of each group are described hereunder and also provided in table 1.

\subsubsection{Mylonite gabbro from off-axis high, north of Vityaz TF}

Samples from off-axis high (DR 01), north of Vityaz TF include principally mylonitic gabbro often gneissic in appearance. They generally display mylonitic texture often porphyroclast locally (figure 2a-d). Fe-Ti oxides (mainly magnetiteilmenite) often wraps against the amphibole veins (figure 2a) or poikilitically host the small clinopyroxene as well as plagioclase grains (figure $2 b, d$ ). Otherwise discrete veins of magnetite-ilmenite cut the dynamically recrystallised plagioclase. Plagioclase and clinopyroxene both occur as porphyroclasts even sometimes twins in plagioclase bend with tapering ends and curvy due to deformation (figure 2c) or sometimes plagioclase exhibit undulatory extinctions (figure 2d). Evidences of local shearing are ascertained due to distinct oxide-rich band that separate from dynamically recrystallised band of plagioclase and clinopyroxene. We note that clinopyroxene porphyroclasts also present with typical 'tail'-like feature. Porphyroclasts sometimes display a shape-preferred elongation parallel to the $\mathrm{Fe}-\mathrm{Ti}$ oxide stringers. Fe-Ti oxides also show typical 'pressure shadow' feature around plagioclase porphyroclast (figure 2c). Amphibole is the principal high-temperature hydrous phase most common in MOR gabbros resulted due to crystallization of evolved hydrous silicate melt or as a product of high temperature water-rock reactions. Both the brown and green variety of amphibole (brown and green hornblende) are present within the mylonite or gneissic gabbro (figure 2a). Locally, they occur isolated or as a cluster or even as band alternate with recrystallised plagioclase, sometimes took the shape of lenses with tapering end (figure 2b). Alteration of clinopyroxene to amphiboles are noticed along the clinopyroxene grain margin or along the fractures developed within the grain (figure 2e). Amphibole shows variegated textures, e.g., locally clusters as subhedral grains, replacement of clinopyroxene and vein amphibole. Chlorite and epidotes are also present locally. Occurrences of epidote are volumetrically 

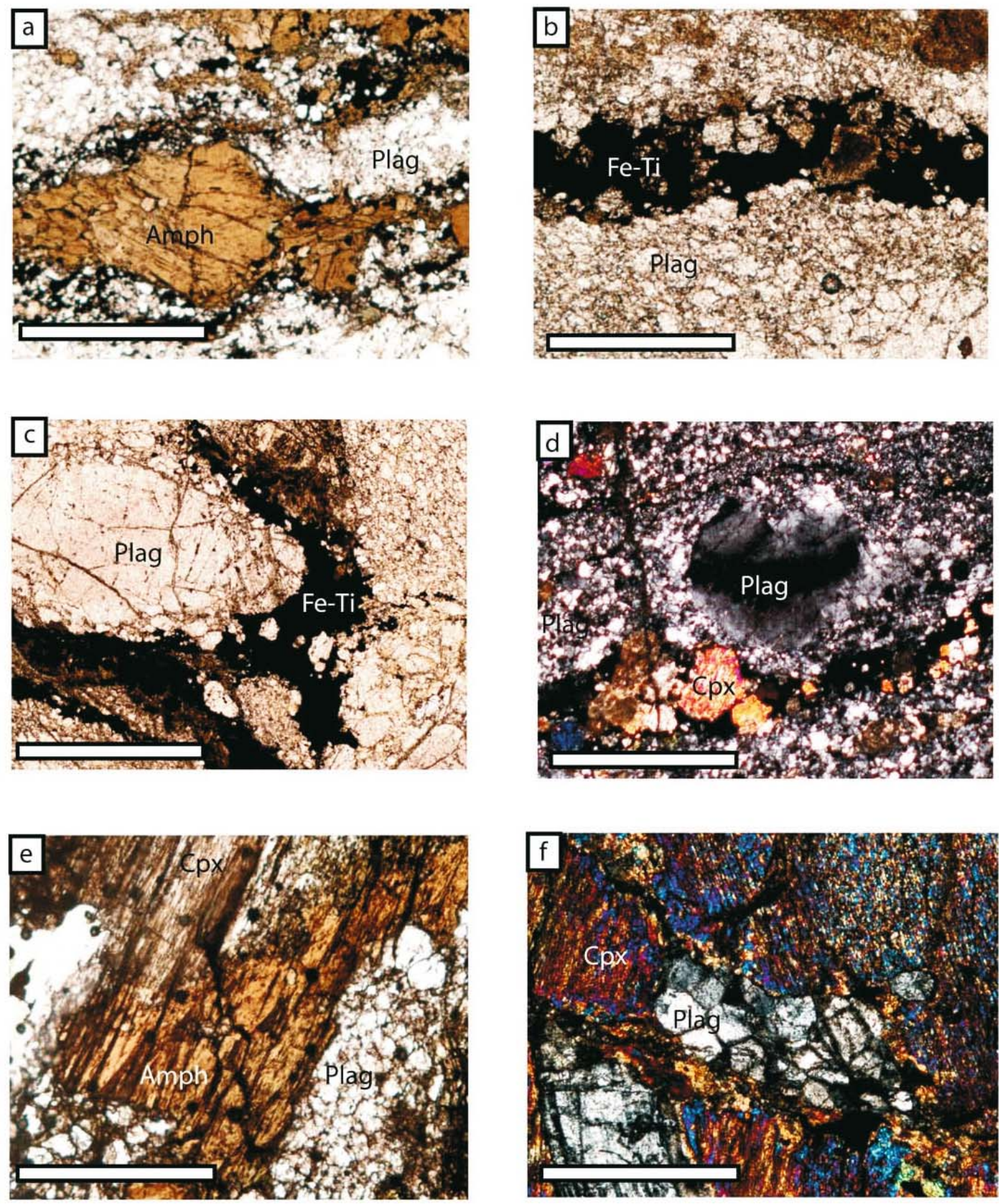

Figure 2. Photomicrographs of mylonitic gabbro from off-axis high (DR 01). (a) Brown amphibole (Amph) intercalated with Fe-Ti oxides (black) form alternating layers with recrystallised plagioclase grains (Plag, white) $(\mathrm{PPL} \times 5 X)$. (b) Fe-Ti oxide veins (black) to host clinopyroxene $(\mathrm{Cpx})$ and amphibole with the recrystallised plagioclase matrix $(\mathrm{PPL} \times 5 \mathrm{X})$. (c) Deformed twins within plagioclase porphyroclast (shape preferred orientation subparallel to the foliation). Matrix composed of fine grained plagioclase $(\mathrm{PPL} \times 5 \mathrm{X})$. (d) Plagioclase showing undulatory extinction. A Fe-Ti vein in the lower half (black) also hosting Cpx grains $(\mathrm{XPL} \times 5 \mathrm{X})$. (e) Alteration of Cpx to amphibole along the margin. Recrystallised plagioclase grains also seen in the matrix $(\mathrm{PPL} \times 10 \mathrm{X})$. (f) Weakly recrystallised plagioclase grains showing triple junction $(\mathrm{XPL} \times 10 \mathrm{X})$. Scale bar: $1 \mathrm{~mm}$ for figure $2(\mathrm{a}-\mathrm{d})$ and $0.5 \mathrm{~mm}$ for figure $2(\mathrm{e}-\mathrm{f})$.

not significant and occur mostly as a vein material or as a replacement of plagioclase in mylonitic gabbro. Plagioclase alteration noticed along fractures and chlorite took its place as fracture filling secondary minerals.
Fe-Ti oxides (magnetite and ilmenite) mostly occur as thick veins or as thin stringers multibranching pattern with dynamically recrystallised plagioclase grains. Sometimes they also occur as big patches or as disseminated grains. Ilmenite 

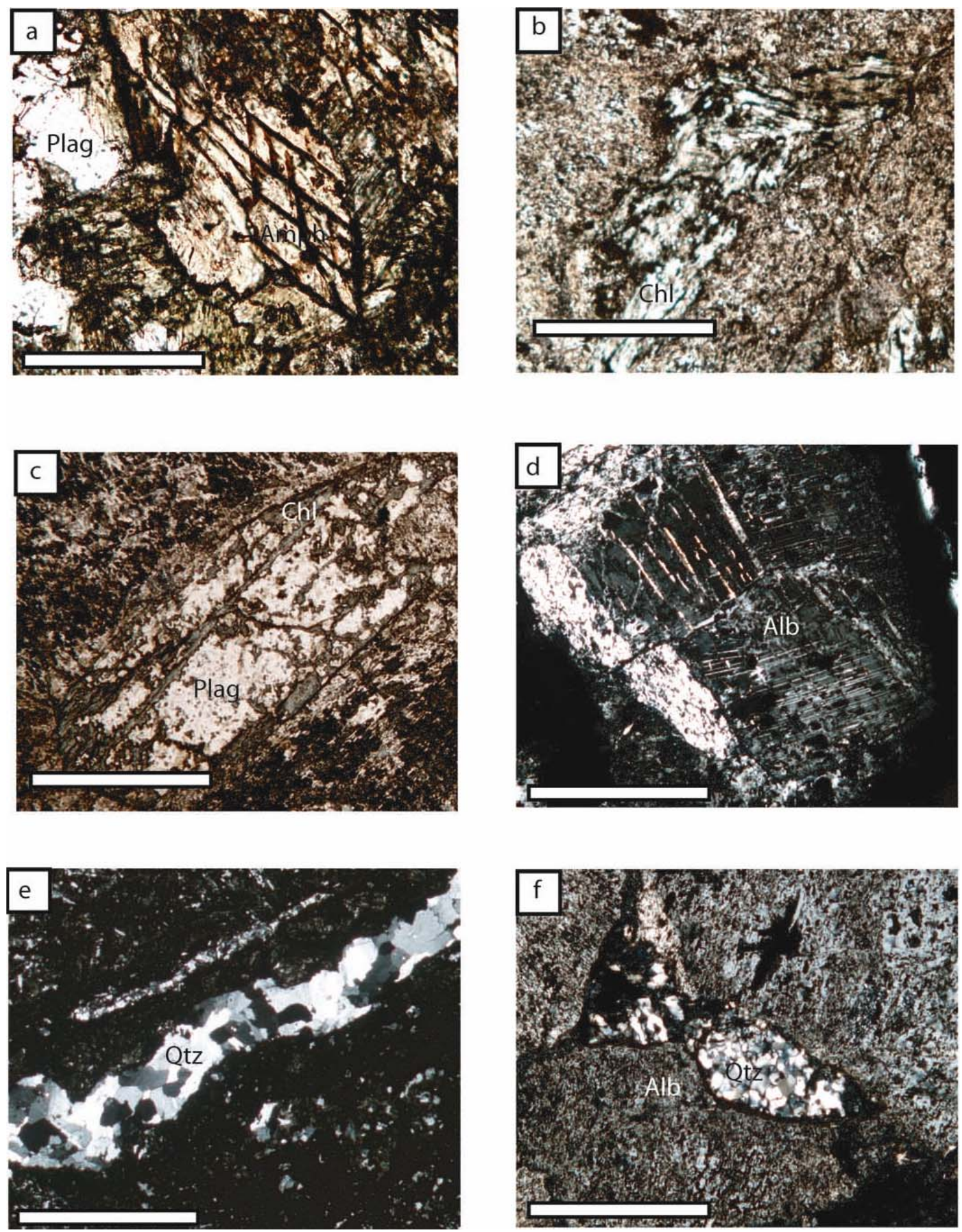

Figure 3. Photomicrographs of altered gabbro from corner-high (station DR 02). (a) Magnesio hornblende (Amph) with prominent cleavage trace $(\mathrm{PPL} \times 10 \mathrm{X})$. (b) Deformed chlorite $(\mathrm{Chl})$ band within albitised matrix $(\mathrm{PPL} \times 5 \mathrm{X})$. $(\mathbf{c}) \mathrm{Chloriti}-$ sation of plagioclase along fractures formed within the plagioclase phenocryst $(\mathrm{PPL} \times 5 \mathrm{X})$. (d) Twinning within albite $($ Alb). $(\mathrm{XPL} \times 10 \mathrm{X})$. (e) Late quartz vein $(\mathrm{Qtz})$. (XPL $\times 5 \mathrm{X})$. (f) Recrystallised Qtz grains enclosed by albite (Alb) phenocrysts $(\mathrm{XPL} \times 5 \mathrm{X})$. Scale bar: $0.5 \mathrm{~mm}$ for figure $2(\mathrm{a}, \mathrm{d})$ and $1 \mathrm{~mm}$ for figure $2(\mathrm{~b}, \mathrm{c}, \mathrm{e}, \mathrm{f})$.

occasionally also preserved exsolution lamellae within the magnetite. Pyrite is also present, even though very rare. Recrystallisation in the weakly recrystallised texture is indicated by the distinct polygonal grains and enclosing grain boundaries with $120^{\circ}$ triple junctions (figure $2 \mathrm{f}$ ). They closely associated with brown amphibole band and the porphyroclasts of plagioclase and clinopyroxene. 
Table 2. Representative analyses of plagioclase from mylonite gabbro. Total iron calculated as FeOt.

\begin{tabular}{|c|c|c|c|c|c|c|c|c|}
\hline Sample no. & DR-01-1 & DR-01-1 & DR-01-1 & DR-01-1 & DR-01-1 & DR-01-1 & DR-01-2 & DR-01-2 \\
\hline \multicolumn{9}{|c|}{ Oxides (wt\%) } \\
\hline $\mathrm{SiO}_{2}$ & 49.71 & 49.18 & 50.19 & 50.07 & 49.44 & 49.55 & 51.54 & 51.39 \\
\hline $\mathrm{TiO}_{2}$ & 0.06 & 0.01 & 0.07 & 0.01 & 0.02 & 0.00 & 0.08 & 0.04 \\
\hline $\mathrm{Al}_{2} \mathrm{O}_{3}$ & 32.04 & 32.13 & 31.60 & 31.81 & 32.20 & 31.86 & 30.04 & 30.23 \\
\hline $\mathrm{Cr}_{2} \mathrm{O}_{3}$ & 0.01 & 0.02 & 0.07 & 0.03 & 0.00 & 0.04 & 0.00 & 0.00 \\
\hline $\mathrm{FeO}_{\mathrm{t}}$ & 0.11 & 0.16 & 0.19 & 0.12 & 0.19 & 0.16 & 0.42 & 0.49 \\
\hline $\mathrm{MnO}$ & 0.00 & 0.07 & 0.01 & 0.00 & 0.05 & 0.01 & 0.01 & 0.00 \\
\hline $\mathrm{MgO}$ & 0.03 & 0.00 & 0.00 & 0.03 & 0.00 & 0.01 & 0.04 & 0.05 \\
\hline $\mathrm{CaO}$ & 14.82 & 14.94 & 14.62 & 14.59 & 14.57 & 14.26 & 12.85 & 12.59 \\
\hline $\mathrm{Na}_{2} \mathrm{O}$ & 2.89 & 2.82 & 3.23 & 3.13 & 3.07 & 3.08 & 4.05 & 4.25 \\
\hline $\mathrm{K}_{2} \mathrm{O}$ & 0.02 & 0.01 & 0.06 & 0.02 & 0.02 & 0.04 & 0.08 & 0.02 \\
\hline $\mathrm{NiO}$ & 0.00 & 0.01 & 0.00 & 0.00 & 0.05 & 0.03 & 0.02 & 0.00 \\
\hline $\mathrm{Cl}$ & 0.02 & 0.00 & 0.00 & 0.00 & 0.00 & 0.01 & 0.01 & 0.02 \\
\hline $\mathrm{P}_{2} \mathrm{O}_{5}$ & n.d. & n.d. & n.d. & n.d. & n.d. & n.d. & 0.05 & 0.00 \\
\hline Total & 99.70 & 99.35 & 100.04 & 99.82 & 99.61 & 99.05 & 99.18 & 99.07 \\
\hline \multicolumn{9}{|c|}{ Cations based on 32 oxygens } \\
\hline $\mathrm{Si}$ & 9.098 & 9.043 & 9.165 & 9.148 & 9.063 & 9.121 & 9.464 & 9.438 \\
\hline $\mathrm{Al}$ & 6.911 & 6.962 & 6.801 & 6.849 & 6.957 & 6.911 & 6.500 & 6.543 \\
\hline $\mathrm{Fe}(\mathrm{II})$ & 0.017 & 0.025 & 0.029 & 0.018 & 0.029 & 0.025 & 0.064 & 0.075 \\
\hline $\mathrm{Ca}$ & 2.906 & 2.943 & 2.860 & 2.856 & 2.861 & 2.812 & 2.528 & 2.477 \\
\hline $\mathrm{Na}$ & 1.025 & 1.005 & 1.144 & 1.109 & 1.091 & 1.099 & 1.442 & 1.513 \\
\hline K & 0.005 & 0.002 & 0.014 & 0.005 & 0.005 & 0.009 & 0.019 & 0.005 \\
\hline Catsum & 19.962 & 19.980 & 20.013 & 19.984 & 20.006 & 19.978 & 20.017 & 20.050 \\
\hline An & 73.83 & 74.50 & 71.19 & 71.95 & 72.30 & 71.73 & 63.38 & 62.01 \\
\hline $\mathrm{Ab}$ & 26.05 & 25.45 & 28.46 & 27.93 & 27.60 & 28.03 & 36.15 & 37.88 \\
\hline
\end{tabular}

\subsubsection{Altered gabbro from corner high, Vityaz TF}

Samples collected from inside corner high of Vityaz TF (DR 02) are mainly broken and altered gabbro (figure 3a-f) often similar to cataclastics. The rocks look green coloured and frequently fractured. We note that extensive veins and vein networks of chlorite \pm epidote \pm quartz, fractured plagioclase and pyroxene grains set in a matrix. Texture is mostly brecciated. Signature of any plastic deformation or mylonitisation is totally absent within altered gabbro even though deformation features are well exemplified in mineral fabric. Plagioclase is the dominant phenocryst phase and are angular, fractured, twined. Plagioclase spectacularly shows microcline and albite twin (figure 3d). Relict plagioclase grains commonly exhibit weak undulose extinction and contain tapering twins often fractured also. Chlorite occurs along the fractures of the plagioclase or as deformed wavy bands or sometimes develop a schistosity (figure 3b, c). Recrystallised quartz vein occurs as secondary vein filling (figure 3e, f) or as mosaic aggregates. Quartz is common, although not voluminous; occur as recrystallised vein closely associated with albite. Typically quartz is colourless to white and devoid of any inclusion. Hornblende mostly occurs as individual or as locally cluster at one place (figure 3a).

\subsection{Mineralogy and mineral chemistry}

\subsubsection{Plagioclase}

Representative plagioclase compositions are given in tables 2 and 3 respectively. Anorthite content (An) of the plagioclase from mylonitic gabbro varies from relatively high $\mathrm{An}\left(\mathrm{An}_{71-75}\right)$ to low $\mathrm{An}$ $\left(\mathrm{An}_{62-66}\right)$.

In contrast, gabbros from corner high include labradorite and albite both. Albite composition from altered gabbro varies from $\mathrm{Ab}_{91}$ to $\mathrm{Ab}_{96}$. Labradorite plagioclase mostly display the intermediate $\mathrm{Ab}$ composition $\left(\mathrm{Ab}_{53}\right.$ to $\mathrm{Ab}_{62}$, figure 4$)$. The intermediate member of plagioclase is missing. Secondary plagioclase is identified by its sodic nature and has a slightly higher $\mathrm{K}_{2} \mathrm{O}$ content than the associated magmatic plagioclase. However, $\mathrm{K}_{2} \mathrm{O}$ is always below $0.5 \mathrm{wt} \%$ (mostly 0.03 
Table 3. Representative analyses of plagioclase from altered gabbro.

\begin{tabular}{|c|c|c|c|c|c|c|c|c|c|}
\hline Sample no. & DR-02-1 & DR-02-1 & DR-02-1 & DR-02-1 & DR-02-1 & DR-02-1 & DR-02-1 & DR-02-1 & DR-02-1 \\
\hline \multicolumn{10}{|c|}{ Oxides (wt\%) } \\
\hline $\mathrm{SiO}_{2}$ & 66.87 & 68.18 & 68.27 & 65.89 & 67.62 & 68.74 & 56.31 & 55.55 & 54.74 \\
\hline $\mathrm{TiO}_{2}$ & 0.03 & 0.04 & 0.00 & 0.05 & 0.00 & 0.02 & 0.03 & 0.06 & 0.06 \\
\hline $\mathrm{Al}_{2} \mathrm{O}_{3}$ & 21.01 & 20.15 & 19.96 & 19.56 & 20.64 & 20.04 & 28.11 & 27.81 & 28.09 \\
\hline $\mathrm{Cr}_{2} \mathrm{O}_{3}$ & 0.02 & 0.06 & 0.01 & 0.00 & 0.00 & 0.00 & 0.08 & 0.00 & 0.00 \\
\hline $\mathrm{FeO}_{\mathrm{t}}$ & 0.06 & 0.05 & 0.13 & 0.49 & 0.03 & 0.05 & 0.39 & 0.34 & 0.17 \\
\hline $\mathrm{MnO}$ & 0.04 & 0.00 & 0.00 & 0.06 & 0.00 & 0.03 & 0.00 & 0.08 & 0.06 \\
\hline $\mathrm{MgO}$ & 0.02 & 0.04 & 0.01 & 0.91 & 0.00 & 0.01 & 0.03 & 0.00 & 0.05 \\
\hline $\mathrm{CaO}$ & 1.66 & 0.85 & 0.69 & 0.75 & 1.39 & 0.82 & 9.54 & 9.86 & 10.33 \\
\hline $\mathrm{Na}_{2} \mathrm{O}$ & 9.89 & 10.80 & 10.30 & 10.12 & 9.88 & 10.63 & 5.30 & 5.38 & 5.13 \\
\hline $\mathrm{K}_{2} \mathrm{O}$ & 0.07 & 0.04 & 0.05 & 0.07 & 0.05 & 0.01 & 0.05 & 0.03 & 0.01 \\
\hline $\mathrm{NiO}$ & 0.03 & 0.00 & 0.04 & 0.00 & 0.09 & 0.00 & 0.00 & 0.05 & 0.05 \\
\hline $\mathrm{Cl}$ & 0.01 & 0.04 & 0.01 & 0.03 & 0.02 & 0.00 & 0.01 & 0.01 & 0.00 \\
\hline Total & 99.71 & 100.23 & 99.47 & 97.93 & 99.72 & 100.34 & 99.84 & 99.18 & 98.70 \\
\hline \multicolumn{10}{|c|}{ Cations based on 32 oxygens } \\
\hline $\mathrm{Si}$ & 11.735 & 11.894 & 11.958 & 11.884 & 11.834 & 11.947 & 10.139 & 10.080 & 9.991 \\
\hline $\mathrm{Al}$ & 4.345 & 4.143 & 4.120 & 4.158 & 4.257 & 4.105 & 5.965 & 5.947 & 6.042 \\
\hline $\mathrm{Fe}(\mathrm{II})$ & 0.009 & 0.007 & 0.019 & 0.074 & 0.004 & 0.004 & 0.005 & 0.052 & 0.026 \\
\hline $\mathrm{Ca}$ & 0.312 & 0.159 & 0.129 & 0.145 & 0.261 & 0.153 & 1.840 & 1.917 & 2.020 \\
\hline $\mathrm{Na}$ & 3.365 & 3.653 & 3.498 & 3.539 & 3.352 & 3.582 & 1.850 & 1.893 & 1.815 \\
\hline $\mathrm{K}$ & 0.016 & 0.009 & 0.011 & 0.016 & 0.011 & 0.002 & 0.011 & 0.007 & 0.002 \\
\hline Catsum & 19.782 & 19.865 & 19.476 & 19.815 & 19.719 & 19.793 & 19.810 & 19.896 & 19.897 \\
\hline An & 8.45 & 4.16 & 3.56 & 3.92 & 7.19 & 4.09 & 49.71 & 50.23 & 52.64 \\
\hline $\mathrm{Ab}$ & 91.12 & 95.61 & 96.13 & 95.65 & 92.50 & 95.85 & 49.98 & 49.59 & 47.30 \\
\hline Or & 0.42 & 0.23 & 0.31 & 0.44 & 0.31 & 0.06 & 0.31 & 0.18 & 0.06 \\
\hline
\end{tabular}

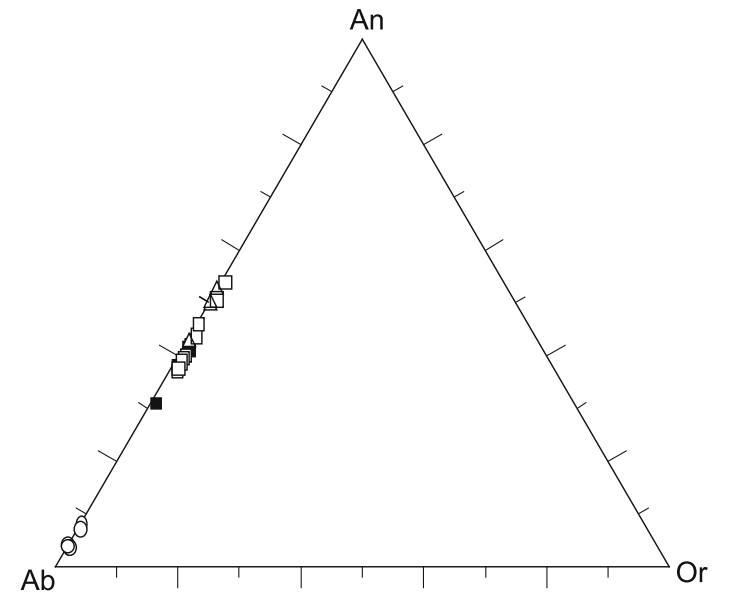

Figure 4. An-Ab-Or ternary plot of plagioclases from mylonite gabbro (DR 01) and altered gabbro (DR 02). Open triangles and open circles represent plagioclase and albite from altered gabbro. Filled and open squares represent plagioclases from mylonite gabbro. An: Anorthite, Ab: Albite, Or: Orthoclase.

to $0.07 \mathrm{wt} \%$ ), similar to secondary plagioclases reported from other oceanic altered gabbros (Mevel 1984; Marion et al 1991). Secondary plagioclases range from albite in some samples to oligoclase and andesine in others. It has also been noticed that secondary plagioclase in altered gabbros dredged from the Mid-Cayman Rise, altered under upper greenschist to lower amphibolite facies conditions (Ito and Clayton 1983). Thus, it is highly unlikely that the albite-rich alteration assemblage in the altered gabbro could have formed at temperatures much greater than $300^{\circ} \mathrm{C}$, which is similar to that have been described earlier from Hole 504B, MidAtlantic Ridge. Also the associated mineral assemblage, presence of chlorite and epidote suggest the low temperature paragenesis for albite.

\subsubsection{Clinopyroxene}

Compositions of clinopyroxene from both in the altered gabbro and mylonitic gabbro are given in table 4. Present clinopyroxene composition varies from $\mathrm{Wo}_{42} \mathrm{En}_{38} \mathrm{Fs}_{6}$ to $\mathrm{Wo}_{48} \mathrm{En}_{49} \mathrm{Fs}_{14}$ and plotted in Wo:En:Fs ternary diagram (figure 5). The clinopyroxene from mylonite zone are more diopsidic compared to clinopyroxene away from the mylonite zone and they plot away from the diopside-end in the same diagram (figure 5). $\mathrm{Al}_{2} \mathrm{O}_{3}$ content of clinopyroxene porphyroclast is comparatively low (as low as $0.16 \mathrm{wt} \%$, table 4). Similar relationships between magmatic and secondary 
Table 4(a). Representative analyses of magmatic clinopyroxene.

\begin{tabular}{|c|c|c|c|c|c|c|c|}
\hline Sample no. & DR-01-1 & DR-01-1 & DR-01-1 & DR-01-1 & DR-01-1 & DR-01-2 & DR-01-2 \\
\hline \multicolumn{8}{|c|}{ Oxides (wt\%) } \\
\hline $\mathrm{SiO}_{2}$ & 53.65 & 53.15 & 52.39 & 53.92 & 54.32 & 52.37 & 52.43 \\
\hline $\mathrm{TiO}_{2}$ & 0.22 & 0.22 & 0.16 & 0.19 & 0.01 & 0.40 & 0.42 \\
\hline $\mathrm{Al}_{2} \mathrm{O}_{3}$ & 1.98 & 1.16 & 1.64 & 1.43 & 0.16 & 2.80 & 2.51 \\
\hline $\mathrm{Cr}_{2} \mathrm{O}_{3}$ & 0.23 & 0.15 & 0.14 & 0.23 & 0.06 & 0.18 & 0.18 \\
\hline $\mathrm{FeO}_{\mathrm{t}}$ & 5.25 & 8.10 & 4.03 & 4.24 & 5.98 & 6.06 & 6.11 \\
\hline $\mathrm{MnO}$ & 0.36 & 0.19 & 0.12 & 0.13 & 0.27 & 0.14 & 0.22 \\
\hline $\mathrm{MgO}$ & 16.75 & 15.32 & 17.07 & 16.76 & 15.23 & 16.16 & 16.27 \\
\hline $\mathrm{CaO}$ & 19.89 & 21.90 & 23.10 & 23.25 & 24.44 & 21.60 & 21.91 \\
\hline $\mathrm{Na}_{2} \mathrm{O}$ & 0.47 & 0.28 & 0.35 & 0.16 & 0.12 & 0.30 & 0.33 \\
\hline $\mathrm{K}_{2} \mathrm{O}$ & 0.04 & 0.02 & 0.03 & 0.00 & 0.01 & 0.00 & 0.00 \\
\hline $\mathrm{NiO}$ & 0.07 & 0.01 & 0.00 & 0.00 & 0.01 & 0.00 & 0.03 \\
\hline $\mathrm{Cl}$ & 0.65 & 0.02 & 0.06 & 0.05 & 0.03 & 0.00 & 0.00 \\
\hline \multicolumn{8}{|l|}{$\mathrm{P}_{2} \mathrm{O}_{5}$} \\
\hline Total & 99.56 & 100.51 & 99.09 & 100.37 & 100.63 & 100.00 & 100.42 \\
\hline \multicolumn{8}{|c|}{ Cations based on 6 oxygens } \\
\hline $\mathrm{Si}$ & 1.976 & 1.964 & 1.939 & 1.965 & 1.996 & 1.925 & 1.924 \\
\hline $\mathrm{Ti}$ & 0.006 & 0.006 & 0.004 & 0.005 & 0 & 0.011 & 0.012 \\
\hline $\mathrm{Al}$ & 0.086 & 0.05 & 0.072 & 0.062 & 0.007 & 0.121 & 0.109 \\
\hline $\mathrm{Cr}$ & 0.007 & 0.004 & 0.004 & 0.007 & 0.002 & 0.005 & 0.005 \\
\hline $\mathrm{Fe}$ & 0.162 & 0.25 & 0.125 & 0.129 & 0.184 & 0.186 & 0.188 \\
\hline $\mathrm{Mn}$ & 0.011 & 0.006 & 0.004 & 0.004 & 0.008 & 0.004 & 0.007 \\
\hline $\mathrm{Mg}$ & 0.92 & 0.844 & 0.942 & 0.91 & 0.834 & 0.885 & 0.89 \\
\hline $\mathrm{Ca}$ & 0.785 & 0.867 & 0.916 & 0.908 & 0.963 & 0.851 & 0.862 \\
\hline $\mathrm{Na}$ & 0.034 & 0.02 & 0.025 & 0.012 & 0.009 & 0.021 & 0.024 \\
\hline K & 0.002 & 0.001 & 0.001 & 0 & 0.001 & 0 & 0 \\
\hline Catsum & 3.989 & 4.012 & 4.032 & 4.002 & 4.004 & 4.009 & 4.021 \\
\hline Wo & 42.05 & 44.21 & 46.19 & 46.64 & 48.61 & 44.28 & 44.43 \\
\hline En & 49.28 & 43.04 & 47.50 & 46.74 & 42.10 & 46.05 & 45.88 \\
\hline Fs & 8.68 & 12.75 & 6.30 & 6.63 & 9.29 & 9.68 & 9.69 \\
\hline $\mathrm{Mg} \#$ & 85.03 & 77.15 & 88.28 & 87.58 & 81.93 & 82.63 & 82.56 \\
\hline
\end{tabular}

$\mathrm{Mg} \#$ mole $\mathrm{Mg}^{2+} /$ mole $\left(\mathrm{Mg}^{2+}+\mathrm{Fe}^{2+}\right)$.

pyroxene have been documented in oceanic gabbros elsewhere (Mevel 1987; Vanko and Stakes 1991; Gillis et al 1993; Tartarotti et al 1998). A few of the present clinopyroxene porphyroclast are also enriched in $\mathrm{MnO}$ (up to $0.64 \mathrm{wt} \%$ ). Clinopyroxene is comparatively rich in iron in the mylonite gabbro (up to $10.5 \mathrm{wt} \%$ ). A binary diagram has been incorporated to display the variation of $\mathrm{FeO}_{\mathrm{t}}$ and $\mathrm{MnO}$ (figure 6). Clinopyroxene in mylonitic gabbro (mostly porphyroclasts) are consistently high in $\mathrm{FeO}_{\mathrm{t}}$ and $\mathrm{MnO}$ content as compared to clinopyroxene away from the mylonite zone.

The composition of the clinopyroxene porphyroclast suggests their formation at a restricted temperature $\left(600^{\circ}-900^{\circ} \mathrm{C}\right)$ which is comparatively less than the formation temperature of clinopyroxene away from mylonite zone (figure 5, Bird et al 1986). Clinopyroxenes exhibiting different textural pattern fall in the different range of temperatures have also been well reported from MARK area (Gillis et al 1993) as well as in the gabbros from Hole 735B in the Indian Ocean (Stakes et al 1991). Orthopyroxene is not observed in the present samples. Olivine is rare constituent for either altered or mylonitic gabbros.

\subsubsection{Amphibole}

Amphiboles from corner-high altered gabbro are magnesio hornblende in the terminology of Leake, 1978 replaced clinopyroxene, while the vein hornblendes (brown hornblende) of mylonitic gabbro from megamullion are mostly edinitic hornblende. In amphibole binary diagram $\left(\mathrm{Al}^{\mathrm{IV}}\right.$ vs. $(\mathrm{Na}+\mathrm{K})_{\mathrm{A}}$ diagram), magnesio hornblende mostly fall under actinolitic hornblende field, are generally Ti poor $(<1 \mathrm{wt} \%)$ as compared to edinitic hornblende of mylonitic gabbro (Ti-rich, maximum $\mathrm{TiO}_{2}$ up to $3 \mathrm{wt} \%$, figure 7 , table 5). However, the 
Table 4(b). Representative analyses of vein clinopyroxene.

\begin{tabular}{|c|c|c|c|c|c|c|c|c|c|}
\hline Sample no. & DR-01-3 & DR-01-3 & DR-01-3 & DR-01-3 & DR-01-3 & DR-01-3 & DR-01-3 & DR-01-3 & DR-01-3 \\
\hline \multicolumn{10}{|c|}{ Oxides (wt\%) } \\
\hline $\mathrm{SiO}_{2}$ & 51.20 & 51.43 & 50.87 & 51.94 & 52.64 & 52.48 & 51.78 & 51.40 & 51.53 \\
\hline $\mathrm{TiO}_{2}$ & 0.46 & 0.55 & 0.36 & 0.39 & 0.28 & 0.19 & 0.32 & 0.39 & 0.45 \\
\hline $\mathrm{Al}_{2} \mathrm{O}_{3}$ & 1.13 & 1.27 & 1.15 & 1.12 & 1.16 & 0.99 & 1.18 & 1.19 & 1.14 \\
\hline $\mathrm{Cr}_{2} \mathrm{O}_{3}$ & 0.00 & 0.05 & 0.00 & 0.04 & 0.03 & 0.00 & 0.03 & 0.00 & 0.00 \\
\hline $\mathrm{FeO}_{\mathrm{t}}$ & 14.01 & 13.70 & 12.44 & 11.79 & 12.06 & 12.40 & 12.92 & 14.04 & 16.49 \\
\hline $\mathrm{MnO}$ & 0.64 & 0.55 & 0.39 & 0.50 & 0.41 & 0.35 & 0.42 & 0.55 & 0.55 \\
\hline $\mathrm{MgO}$ & 12.17 & 11.80 & 11.92 & 12.42 & 12.25 & 12.94 & 12.41 & 12.11 & 12.80 \\
\hline $\mathrm{CaO}$ & 19.11 & 19.22 & 19.93 & 20.16 & 20.43 & 19.98 & 19.85 & 20.24 & 16.81 \\
\hline $\mathrm{Na}_{2} \mathrm{O}$ & 0.35 & 0.45 & 0.36 & 0.36 & 0.31 & 0.34 & 0.32 & 0.35 & 0.28 \\
\hline $\mathrm{K}_{2} \mathrm{O}$ & 0.00 & 0.01 & 0.00 & 0.02 & 0.00 & 0.01 & 0.04 & 0.03 & 0.02 \\
\hline $\mathrm{NiO}$ & 0.03 & 0.11 & 0.05 & 0.00 & 0.00 & 0.00 & 0.00 & 0.07 & 0.15 \\
\hline $\mathrm{Cl}$ & 0.00 & 0.00 & 0.00 & 0.00 & 0.03 & 0.01 & 0.00 & 0.00 & 0.00 \\
\hline $\mathrm{P}_{2} \mathrm{O}_{5}$ & 0.00 & 0.00 & 0.04 & 0.00 & 0.02 & 0.03 & 0.04 & 0.02 & 0.04 \\
\hline Total & 99.09 & 99.14 & 97.50 & 98.73 & 99.61 & 99.72 & 99.29 & 100.39 & 100.26 \\
\hline \multicolumn{10}{|c|}{ Cations based on 6 oxygens } \\
\hline $\mathrm{Si}$ & 1.965 & 1.971 & 1.976 & 1.982 & 1.991 & 1.984 & 1.974 & 1.955 & 1.964 \\
\hline $\mathrm{Al}$ & 0.051 & 0.057 & 0.052 & 0.05 & 0.052 & 0.044 & 0.053 & 0.053 & 0.051 \\
\hline $\mathrm{Ti}$ & 0.013 & 0.016 & 0.01 & 0.011 & 0.008 & 0.005 & 0.009 & 0.011 & 0.013 \\
\hline $\mathrm{Cr}$ & 0 & 0.002 & 0 & 0.001 & 0.001 & 0 & 0.001 & 0 & 0 \\
\hline $\mathrm{Fe}$ & 0.45 & 0.439 & 0.404 & 0.376 & 0.381 & 0.392 & 0.412 & 0.447 & 0.526 \\
\hline $\mathrm{Mn}$ & 0.021 & 0.018 & 0.013 & 0.016 & 0.013 & 0.011 & 0.013 & 0.018 & 0.018 \\
\hline $\mathrm{Mg}$ & 0.696 & 0.674 & 0.69 & 0.706 & 0.691 & 0.729 & 0.705 & 0.686 & 0.728 \\
\hline $\mathrm{Ca}$ & 0.786 & 0.789 & 0.829 & 0.824 & 0.828 & 0.81 & 0.81 & 0.824 & 0.687 \\
\hline $\mathrm{Na}$ & 0.026 & 0.033 & 0.027 & 0.027 & 0.022 & 0.025 & 0.024 & 0.026 & 0.021 \\
\hline K & 0 & 0.001 & 0 & 0.001 & 0 & 0.001 & 0.002 & 0.001 & 0.001 \\
\hline Catsum & 4.008 & 4 & 4.001 & 3.994 & 3.987 & 4.001 & 4.003 & 4.021 & 4.009 \\
\hline Wo & 39.74 & 41.48 & 43.11 & 43.23 & 43.58 & 41.95 & 42.03 & 42.11 & 35.39 \\
\hline En & 35.2 & 35.44 & 35.88 & 37.04 & 36.37 & 37.75 & 36.59 & 35.05 & 37.51 \\
\hline Fs & 23.74 & 23.08 & 21.01 & 19.73 & 20.05 & 20.30 & 21.38 & 22.84 & 27.10 \\
\hline $\mathrm{Mg} \#$ & 60.73 & 60.56 & 63.07 & 65.25 & 64.46 & 65.03 & 63.12 & 60.55 & 58.05 \\
\hline
\end{tabular}

$\mathrm{Mg} \#$ mole $\mathrm{Mg}^{2+} /$ mole $\left(\mathrm{M}^{2+}+\mathrm{Fe}^{2+}\right)$.

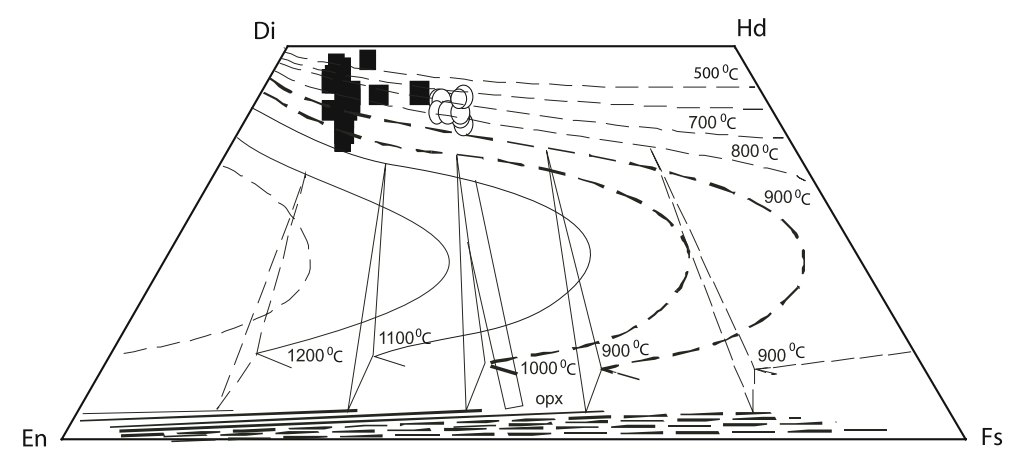

Figure 5. Di-Hd-En-Fs quadrilateral of clinopyroxene (Cpx). Filled squares and open circles both represent clinopyroxene from mylonitic gabbro. Open circle data represents Cpx porphyroclast. Temperature curves drawn after Bird et al (1986). Di: Diopside, Hd: Hedenbergite, En: Enstatite and Fs: Ferosilite.

colour of edenite in veins vary from greenish tint to more brown as the Ti content increases. Their characteristics are high in $\mathrm{TiO}_{2}(>1 \mathrm{wt} \%)$ and $\mathrm{Al}_{2} \mathrm{O}_{3}$ (9-11 wt\%) contents, sometimes have a low $\mathrm{Cl}$ content $(<0.10 \mathrm{wt} \%)$. They are comparable to the brown high aluminum hornblendes reported from oceanic gabbros elsewhere (Vanko and Stakes 1991; Gillis 1996). These amphiboles are generally considered to be late-magmatic phases directly crystallised from magma or formed by late-magmatic 

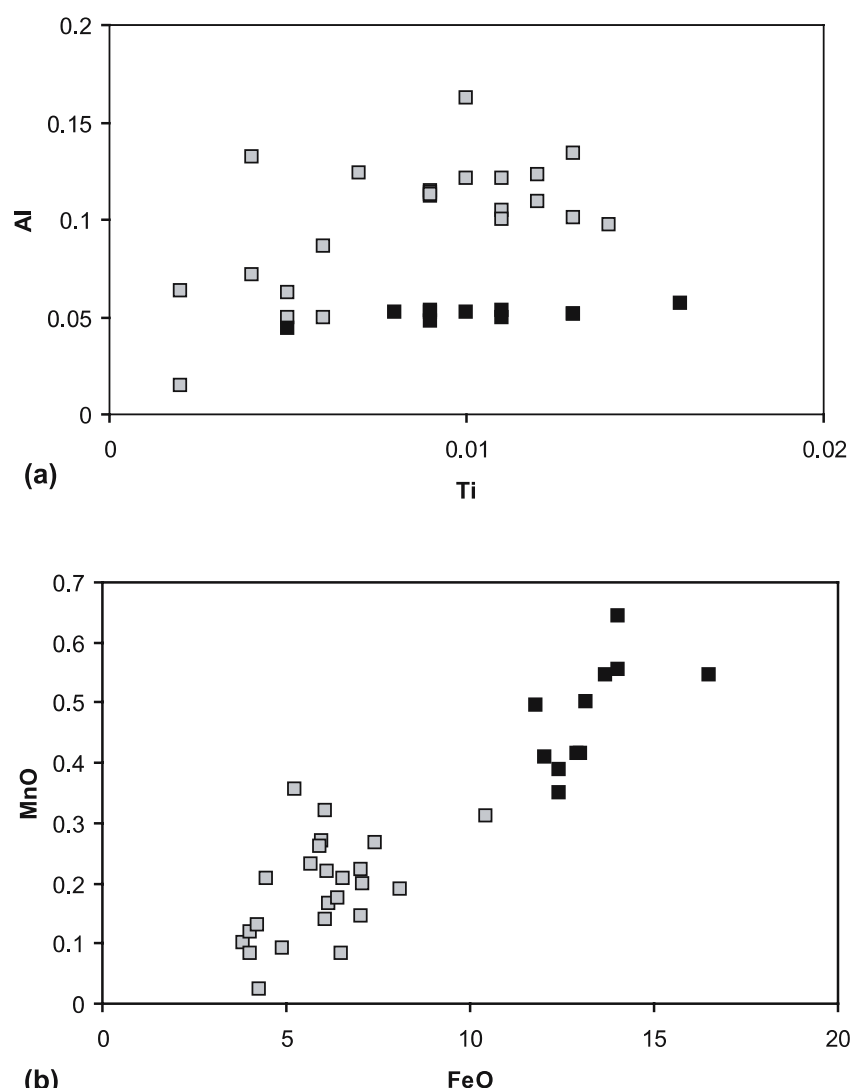

Figure 6. (a) Binary plot of $\mathrm{Al}$ (a.p.f.u) vs. Ti (a.p.f.u) of magmatic and vein Cpx, (b) Binary plot of $\mathrm{MnO}$ (wt\%) vs. $\mathrm{FeO}_{\mathrm{t}}$ (wt\%) of magmatic and porphyroclast of clinopyroxene ( $\mathrm{Cpx}$ ). Open squares represent magmatic Cpx and filled squares represent $\mathrm{Cpx}$ porphyroclast. Both the samples are from mylonite gabbro.

replacement of pyroxene (e.g., Miyashiro and Shido 1980; Mevel 1984; Kagiamanidou 1986; Vanko and Stakes 1991; Marion et al 1991; Gillis 1996). However, present vein amphiboles are Cl-rich and the chlorine concentrations, reach up to $0.62 \mathrm{wt} \% \mathrm{Cl}$, probably represent the products of interaction by anomalously saline hydrothermal fluid. Vein amphiboles show uniformly high $\mathrm{Cl}$ content as compared to the hornblende those have replaced clinopyroxene (figure 8). Also the high $\mathrm{Cl}$ amphiboles show higher $\mathrm{Na}$ and $\mathrm{K}$ content (figure 9). A graph showing $\mathrm{Ti}$ vs. tetrahedral $\mathrm{Al}\left(\mathrm{Al}^{\mathrm{IV}}\right)$ in amphiboles can, in many cases be used to ascertain qualitatively the metamorphic grade of the host rock. Low-grade actinolitic hornblendes have lower $\mathrm{Ti}$ and $\mathrm{Al}^{\mathrm{IV}}$, and higher grade hornblendes have higher $\mathrm{Ti}$ and $\mathrm{Al}^{\mathrm{IV}}$. Actinolitic hornblendes are mostly Si-rich and Al-poor and define a distinct field in $\mathrm{Si} v s . \mathrm{Mg} / \mathrm{Mg}+\mathrm{Fe}$ binary diagram (figure 10). As the $\mathrm{Al}^{\mathrm{IV}}$ content of amphibole is essentially temperature dependent (Moody et al 1983; Blundy and Holland 1990), the difference in concentration of $\mathrm{Al}$ among actinolites and edenite
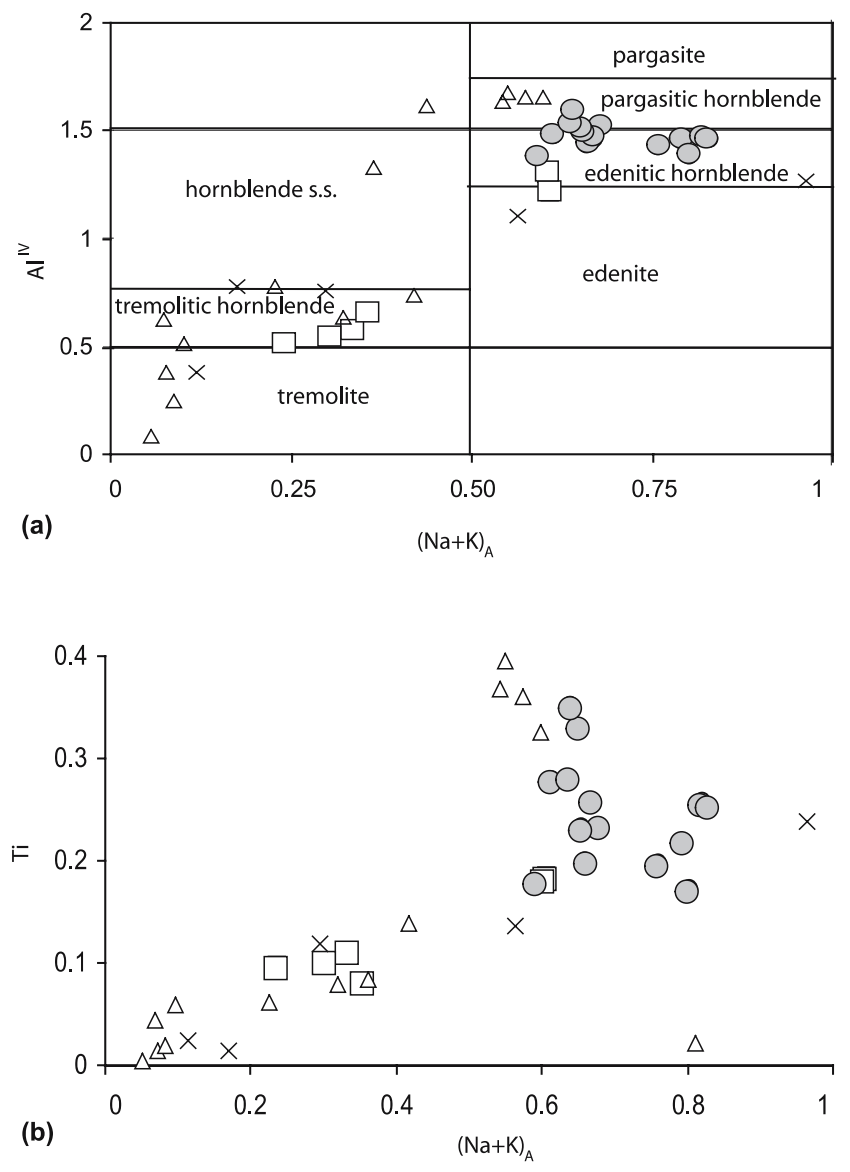

\begin{tabular}{|ll|}
\hline Explanation & \\
$\square$ Altered gabbro & $\triangle$ Hole 735B gabbro \\
$\bigcirc$ Mylonite gabbro & $\times$ Mathematician gabbro
\end{tabular}

Figure 7. Representation of amphiboles in (a) $\mathrm{Al}^{\mathrm{IV}}$ vs. $(\mathrm{Na}+\mathrm{K})_{\mathrm{A}}$ diagram and (b) $\mathrm{Ti}$ vs. $(\mathrm{Na}+\mathrm{K})_{\mathrm{A}}$ diagram. Altered gabbro (DR 02) and mylonite gabbro (DR 01) are from present data. Hole 735B, SWIR and Mathematician gabbro data taken from Stakes et al (1991) and Stakes and Vanko (1986), respectively.

thus allow to estimate the temperatures. They also do not vary to each other but $\mathrm{Al}$ and $\mathrm{Na}$ covary. $\mathrm{CaO}$ is nearly constant $(10-11 \mathrm{wt} \%)$ and $\mathrm{Al}^{\mathrm{VI}}$ is low for all, especially for actinolitic hornblende (DR 02, table 5).

\subsubsection{Epidote}

Representative epidote compositions are given in table 6. The range of $\mathrm{Fe}^{3+} /\left(\mathrm{Fe}^{3+}+\mathrm{Al}^{3+}\right)$ ratios (pistacite content) for individual grains is $<0.23$ (mostly $<0.17)$. The $\mathrm{MnO}$ content of all epidote varies from 0.02 to 0.11 and $\mathrm{TiO}_{2}$ varies from 0.002 to 1.81 ; there is no difference in these minor elements with respect to their occurrence or alteration type. The epidote has nearly constant $\mathrm{SiO}_{2}$ and $\mathrm{CaO}$ but varies significantly in iron and alumina. Weak iron enrichment within the epidote is also 
Table 5. Representative analyses of amphibole.

\begin{tabular}{|c|c|c|c|c|c|c|c|c|c|}
\hline Sample no. & DR-01-1 & DR-01-1 & DR-01-1 & DR-01-1 & DR-01-1 & DR-02-1 & DR-02-1 & DR-02-1 & DR-02-1 \\
\hline \multicolumn{10}{|c|}{ Oxides (wt\%) } \\
\hline $\mathrm{SiO}_{2}$ & 43.53 & 43.61 & 43.37 & 43.58 & 43.23 & 50.06 & 50.74 & 50.92 & 48.52 \\
\hline $\mathrm{TiO}_{2}$ & 1.72 & 1.92 & 2.26 & 1.49 & 2.22 & 0.97 & 0.91 & 0.87 & 0.69 \\
\hline $\mathrm{Al}_{2} \mathrm{O}_{3}$ & 10.20 & 10.50 & 10.30 & 9.73 & 10.20 & 5.08 & 4.83 & 4.40 & 5.17 \\
\hline $\mathrm{Cr}_{2} \mathrm{O}_{3}$ & 0.05 & 0.05 & 0.09 & 0.14 & 0.01 & 0.00 & 0.00 & 0.00 & 0.00 \\
\hline $\mathrm{FeO}_{\mathrm{t}}$ & 14.63 & 14.25 & 14.25 & 14.68 & 15.37 & 14.07 & 13.78 & 14.37 & 12.95 \\
\hline $\mathrm{MnO}$ & 0.20 & 0.20 & 0.14 & 0.17 & 0.12 & 0.23 & 0.22 & 0.35 & 0.21 \\
\hline $\mathrm{MgO}$ & 12.06 & 11.98 & 11.95 & 11.98 & 11.23 & 13.75 & 14.31 & 14.13 & 14.20 \\
\hline $\mathrm{CaO}$ & 10.92 & 11.00 & 10.84 & 11.09 & 10.89 & 10.26 & 10.27 & 10.62 & 10.56 \\
\hline $\mathrm{Na}_{2} \mathrm{O}$ & 2.20 & 2.45 & 2.56 & 2.43 & 2.43 & 1.14 & 1.03 & 0.83 & 1.15 \\
\hline $\mathrm{K}_{2} \mathrm{O}$ & 0.60 & 0.42 & 0.37 & 0.46 & 0.60 & 0.04 & 0.06 & 0.01 & 0.09 \\
\hline $\mathrm{NiO}$ & 0.00 & 0.03 & 0.00 & 0.00 & 0.01 & 0.05 & 0.07 & 0.00 & 0.07 \\
\hline $\mathrm{Cl}$ & 0.49 & 0.15 & 0.09 & 0.58 & 0.51 & 0.07 & 0.04 & 0.00 & 0.02 \\
\hline Total & 96.60 & 96.55 & 96.21 & 96.32 & 96.82 & 95.72 & 96.26 & 96.49 & 93.61 \\
\hline $\mathrm{Si}$ & 6.572 & 6.55 & 6.535 & 6.614 & 6.544 & 7.422 & 7.459 & 7.484 & 7.348 \\
\hline $\mathrm{Al}(\mathrm{IV})$ & 1.428 & 1.45 & 1.465 & 1.386 & 1.456 & 0.578 & 0.541 & 0.516 & 0.652 \\
\hline $\mathrm{T}$ & 8 & 8 & 8 & 8 & 8 & 8 & 8 & 8 & 8 \\
\hline $\mathrm{Al}(\mathrm{VI})$ & 0.387 & 0.408 & 0.365 & 0.354 & 0.363 & 0.309 & 0.295 & 0.246 & 0.27 \\
\hline $\mathrm{Ti}$ & 0.195 & 0.217 & 0.256 & 0.17 & 0.253 & 0.109 & 0.101 & 0.096 & 0.079 \\
\hline $\mathrm{Cr}$ & 0.005 & 0.01 & 0.01 & 0.016 & 0.002 & 0 & 0 & 0 & 0 \\
\hline $\mathrm{Fe}(\mathrm{III})$ & 0 & 0 & 0 & 0 & 0 & 0 & 0 & 0 & 0 \\
\hline $\mathrm{Fe}(\mathrm{II})$ & 1.846 & 1.789 & 1.795 & 1.863 & 1.945 & 1.744 & 1.693 & 1.766 & 1.64 \\
\hline $\mathrm{Mn}$ & 0.025 & 0.025 & 0.018 & 0.022 & 0.015 & 0.029 & 0.027 & 0.044 & 0.026 \\
\hline $\mathrm{Mg}$ & 2.715 & 2.682 & 2.684 & 2.711 & 2.534 & 3.038 & 3.136 & 3.096 & 3.206 \\
\hline $\mathrm{Ca}$ & 1.767 & 1.77 & 1.751 & 1.802 & 1.766 & 1.63 & 1.617 & 1.672 & 1.714 \\
\hline $\mathrm{C}+\mathrm{B}$ & 6.942 & 6.902 & 6.879 & 6.937 & 6.878 & 6.859 & 6.87 & 6.92 & 6.935 \\
\hline $\mathrm{Na}$ & 0.645 & 0.713 & 0.749 & 0.714 & 0.712 & 0.327 & 0.292 & 0.236 & 0.339 \\
\hline $\mathrm{K}$ & 0.115 & 0.08 & 0.071 & 0.089 & 0.117 & 0.008 & 0.012 & 0.002 & 0.017 \\
\hline A & 0.760 & 0.793 & 0.82 & 0.803 & 0.829 & 0.335 & 0.304 & 0.238 & 0.355 \\
\hline $\mathrm{X}_{\mathrm{Ab}}$ & 0.46 & 0.49 & 0.59 & 0.55 & 0.60 & n.a. & n.a. & n.a. & n.a. \\
\hline $\mathrm{T}^{\circ} \mathrm{C}$ & 825 & 818 & 806 & 801 & 796 & n.a. & n.a. & n.a. & n.a. \\
\hline
\end{tabular}

especially one grain shows iron content $\left(\mathrm{FeO}_{\mathrm{t}}\right)$ up to $9 \mathrm{wt} \%$. Present epidote composition show similar range in $\mathrm{Al}-\mathrm{Fe}^{3+}$ substitution (figure 11a). In fact the NCIR gabbroic epidote compositional range overlaps the field of epidote trend in metagabbro of SWIR or MARK (figure 11a).

\subsubsection{Chlorite}

$\mathrm{X}_{\mathrm{Mg}}$ (mole $\mathrm{Mg} /$ mole $\mathrm{Mg}+\mathrm{Fe}$ ) of chlorite varies from 0.76 to 0.85 (table 7 ). $\mathrm{FeO}_{\mathrm{t}}$ content of present chlorite samples are variable (8.36 to $14.32 \mathrm{wt} \%)$. Chlorite of present metagabbro also exhibits high $\mathrm{X}_{\mathrm{Mg}}$ as compared to chlorite from MARK metagabbro (figure 11b).

\subsubsection{Quartz}

As expected the quartz is composed of nearly pure $\mathrm{SiO}_{2}$, occasionally accompanied by trace amounts of $\mathrm{Al}_{2} \mathrm{O}_{3}, \mathrm{TiO}_{2}, \mathrm{FeO}_{\mathrm{t}}$ or $\mathrm{CaO}$. The nonsilica components never exceed $1 \mathrm{wt} \%$ and do not vary with the mode of occurrence of quartz.

\subsubsection{Ilmenite}

Ilmenite contains $1.4-8.5 \% \mathrm{MnO}$ and $0.07-0.09 \%$ $\mathrm{Cr}_{2} \mathrm{O}_{3}$. Titanite also present locally and probably replaces titanomagnetite.

\section{Discussion}

Gabbros from NCIR represent a range of mineral assemblages resulted under variable physical-chemical conditions, high temperature amphibole-rich mylonite gabbros to highly altered greenschists. The gabbros from off-axis high, north of Vityaz TF, after cooling and crystallisation, underwent ductile deformation. A late magmatic stage was associated with intrusion of Fe-Ti rich magma to form the oxide rich layers (figure 2). 

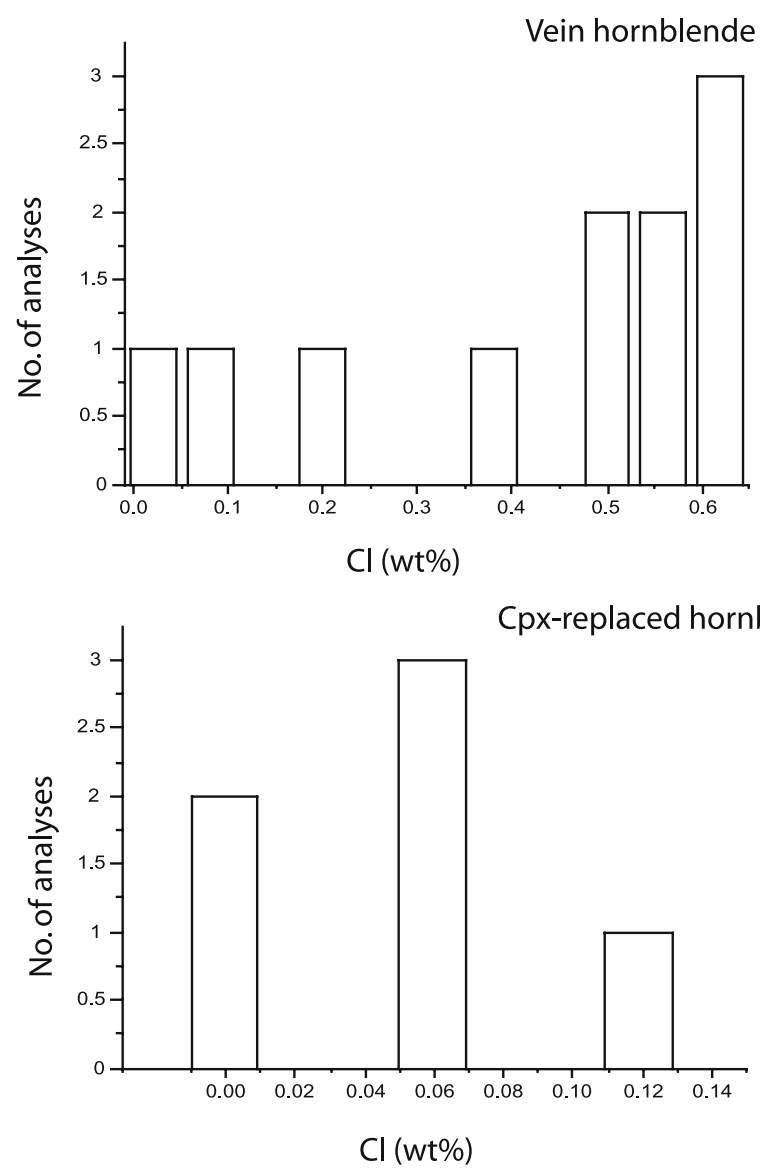

Figure 8. Cl-histogram of vein amphibole and clinopyroxene (Cpx)-replaced amphibole.

In addition, a later stage of subsolidus deformation, produced strongly foliated rocks resulting in the formation of porphyroclastic and mylonitic textures. In contrast, altered gabbro from corner high, adjacent to Vityaz TF, underwent low temperature greenschist grade alteration only with typical greenschist mineralogical assemblages (figure 3 ). The low temperature metamorphic minerals observed in late veins correspond to greenschist facies conditions and lower temperatures formed during cooling of lithosphere once shearing of the rocks (caused due to the presence of active TF) ceased. The brittle deformation of the altered gabbro can be ascertained by the presence of bending of twins, highly fractured and undulatory extinction of plagioclase grains.

\subsection{Condition of mineralogical changes in gabbro}

Mineralogical characters of present gabbro reflect difference in their alteration style due to temperature constraints and mode of emplacement due to tectonic evolution in the present study area. Among the minerals studied, amphibole compositions suggest evolutionary processes of present
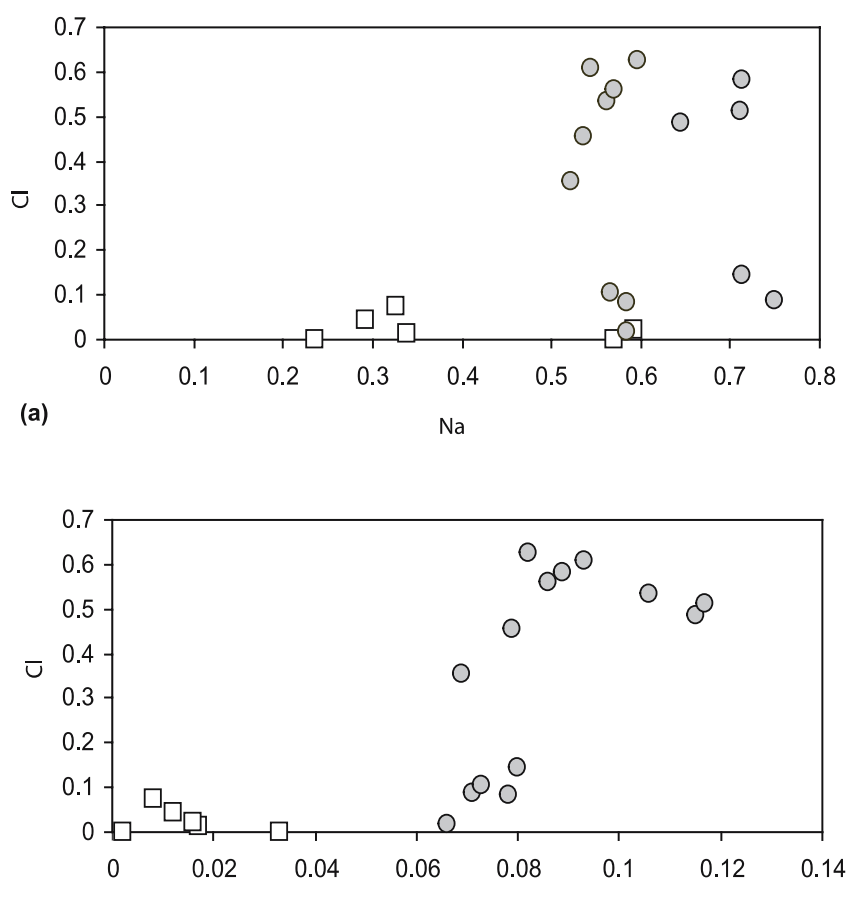

(b)

Figure 9. Representation of amphiboles in binary diagrams of $\mathrm{Cl}(\mathrm{wt} \%$ ) vs. (a) $\mathrm{Na}$ (a.p.f.u) and (b) K (a.p.f.u). Filled circles represent vein amphibole and open squares represent amphiboles replaces Cpx.

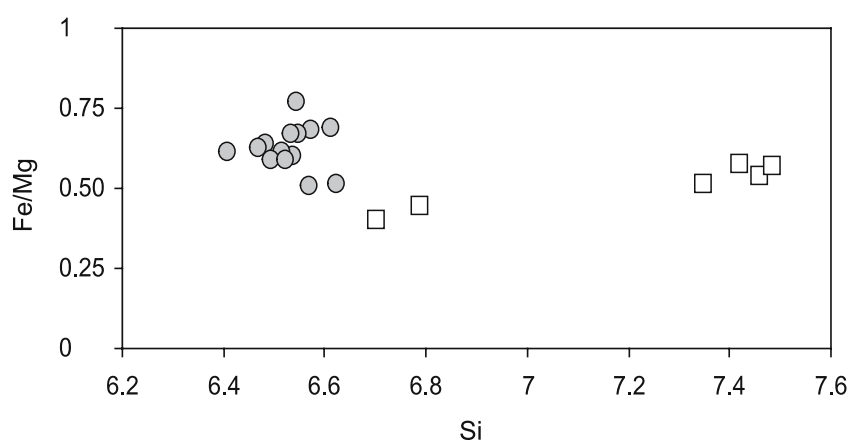

Figure 10. Representation of amphiboles in $\mathrm{Fe} / \mathrm{Mg}$ vs. $\mathrm{Si}$ (a.p.f.u.) binary diagram. Filled circles represent vein amphiboles from mylonite gabbro and open squares represent amphibole from altered gabbro.

gabbro samples. Hornblende most likely to be formed at temperature above $550^{\circ} \mathrm{C}$ (Liou et al $1974)$ to $600^{\circ} \mathrm{C}$ (Spear 1981). The gabbro mineralogy from off-axis high adjacent to Vityaz TF is consistent with sites 921 to 924 of MARK area, Hole $735 \mathrm{~B}$ at the Atlantis fracture Zone along the SWIR. However, characteristic features of the deformation fabrics and metamorphic assemblages in the site 735 gabbros suggest that deformation at Hole $735 \mathrm{~B}$ was started at hypersolidus conditions and continued from granulite to amphibolite facies $\left(550^{\circ}-850^{\circ} \mathrm{C}\right.$, Stakes et al 1991). The formation of brown hornblende and its mineralogy (high $\mathrm{Ti}$ 
Table 6. Representative analyses of epidote. Total iron calculated as $\mathrm{FeO}_{t}$.

\begin{tabular}{|c|c|c|c|c|c|}
\hline Sample no. & DR-01-1 & DR-01-1 & DR-01-1 & DR-01-1 & DR-01-1 \\
\hline \multicolumn{6}{|c|}{ Oxides (wt\%) } \\
\hline $\mathrm{SiO}_{2}$ & 38.79 & 38.45 & 39.84 & 38.82 & 38.48 \\
\hline $\mathrm{TiO}_{2}$ & 0.00 & 0.08 & 0.02 & 1.81 & 0.00 \\
\hline $\mathrm{Al}_{2} \mathrm{O}_{3}$ & 26.35 & 26.29 & 21.98 & 25.41 & 26.87 \\
\hline $\mathrm{Cr}_{2} \mathrm{O}_{3}$ & 0.00 & 0.05 & 0.06 & 0.01 & 0.01 \\
\hline $\mathrm{FeO}_{\mathrm{t}}$ & 7.62 & 7.60 & 9.09 & 6.95 & 7.75 \\
\hline $\mathrm{MnO}$ & 0.10 & 0.03 & 0.09 & 0.11 & 0.11 \\
\hline $\mathrm{MgO}$ & 0.33 & 0.22 & 2.61 & 0.49 & 0.04 \\
\hline $\mathrm{CaO}$ & 23.05 & 23.06 & 20.56 & 23.24 & 23.24 \\
\hline $\mathrm{Na}_{2} \mathrm{O}$ & 0.04 & 0.04 & 0.09 & 0.06 & 0.03 \\
\hline $\mathrm{K}_{2} \mathrm{O}$ & 0.00 & 0.00 & 0.01 & 0.00 & 0.01 \\
\hline $\mathrm{NiO}$ & 0.00 & 0.01 & 0.00 & 0.00 & 0.00 \\
\hline $\mathrm{Cl}$ & 0.00 & 0.00 & 0.02 & 0.00 & 0.02 \\
\hline Total & 96.28 & 95.83 & 94.37 & 96.91 & 96.55 \\
\hline \multicolumn{6}{|c|}{ Cations based on 25 oxygens } \\
\hline $\mathrm{Si}$ & 6.222 & 6.2 & 6.537 & 6.185 & 6.164 \\
\hline $\mathrm{Ti}$ & 0.001 & 0.01 & 0.003 & 0.217 & 0 \\
\hline $\mathrm{Al}$ & 4.982 & 4.999 & 4.252 & 4.774 & 5.074 \\
\hline $\mathrm{Cr}$ & 0 & 0.006 & 0.007 & 0.001 & 0.002 \\
\hline $\mathrm{Fe}^{2+}$ & 1.022 & 1.025 & 1.248 & 0.926 & 1.038 \\
\hline $\mathrm{Mn}$ & 0.014 & 0.004 & 0.013 & 0.014 & 0.015 \\
\hline $\mathrm{Mg}$ & 0.078 & 0.053 & 0.638 & 0.115 & 0.01 \\
\hline $\mathrm{Ca}$ & 3.961 & 3.984 & 3.615 & 3.968 & 3.99 \\
\hline $\mathrm{Na}$ & 0.013 & 0.014 & 0.03 & 0.018 & 0.008 \\
\hline $\mathrm{K}$ & 0.002 & 0 & 0.003 & 0.001 & 0.002 \\
\hline Catsum & 16.295 & 16.295 & 16.346 & 16.219 & 16.303 \\
\hline
\end{tabular}

content, table 5) suggest the formation of present mylonitic gabbro initiated in a rock-dominated system at $700^{\circ} \mathrm{C}$ or higher. In addition, amphibole chemistry also helps to decipher the condition of alteration and chemistry of interacting fluids. Vein amphibole (figure 2a) is a major sink for $\mathrm{Cl}$ and characteristically show Cl-enrichment. Chlorine, a major constituent of sea water thus enters the structure of amphibole during sea water-rock interaction. Thus, $\mathrm{Cl}$ enrichment within the amphibole is totally structurally controlled (table 5). The chlorine composition can also provide useful information on fluid composition. Some of the present aluminous edenitic hornblendes contain significant amount of chlorine (up to $0.62 \mathrm{wt} \%$ ) suggesting formation of sea water-rock interaction (Ito and Anderson 1983; Batiza and Vanko 1985; Vanko 1986; Mevel 1988). Also the restricted occurrences of Cl-rich amphibole (in mylonitic veins only) suggests sea water of a concentrated brine substantially influences its formation at the time of mylonitisation (figure 8). Additionally, the Cl-rich amphibole are uniformly $\mathrm{Na}$ and K-rich $\left(\mathrm{Na}_{2} \mathrm{O}>2\right.$ and $\mathrm{K}_{2} \mathrm{O}>0.4 \mathrm{wt} \%$, table 5, figure 9). Though, interaction of high temperature magmatic Cl-rich fluids in gabbroic rocks well reported from Kane fracture Zone, Mid-Atlantic Ridge (Kelley and Delaney 1987), Cl-rich amphiboles from present study seems to be the result of sea water circulation. The $\mathrm{Na}$ and $\mathrm{K}$ vs. $\mathrm{Cl}$ diagrams suggest the interacting fluid phase particularly enriched in $\mathrm{Na}, \mathrm{K}$ and $\mathrm{Cl}$.

There is difference in compositions between hornblende replaces primary phases (hence clinopyroxenes) and those filling veins. The $\mathrm{Al}$ content of amphibole increases with increasing metamorphic grade (Deer et al 1992), as noticed in mylonitic gabbro and the low $\mathrm{Al}$ actinolitic hornblende $\left(\sim \mathrm{Al}_{2} \mathrm{O}_{3}\right.$ value goes down up to $\left.4.83 \mathrm{wt} \%\right)$ of altered gabbro from corner high also supports their low temperature metamorphic mineralogical assemblages (figure 7). In addition, low $\mathrm{Ti}$ $\left(\mathrm{TiO}_{2}\right.$ always less than $\left.1 \mathrm{wt} \%\right)$ favourably suggest their formation at low temperatures. The typical mineralogical assemblages of corner high gabbro suggest that altered gabbroic rocks underwent brittle deformation and associated hydrothermal alteration to greenschist assemblages. Based on metamorphic grade and the pattern of elemental enrichments, we infer that the present gabbro was altered in the deeper levels by the hydrothermal systems. At shallow levels $(<1 \mathrm{~km})$ and recharge 


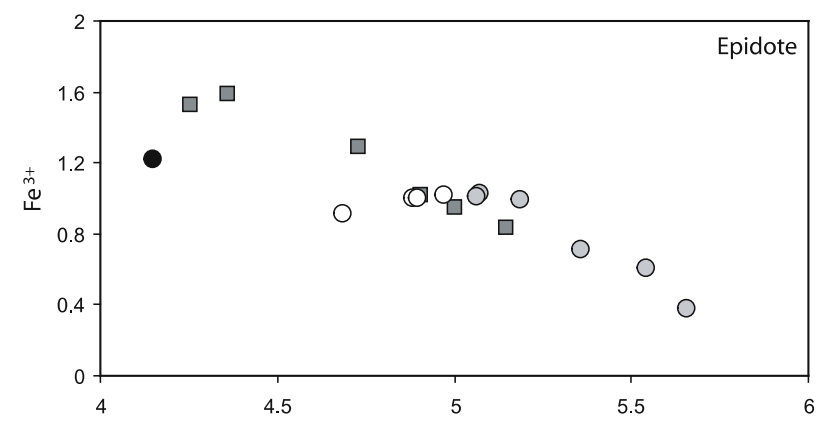

(a)

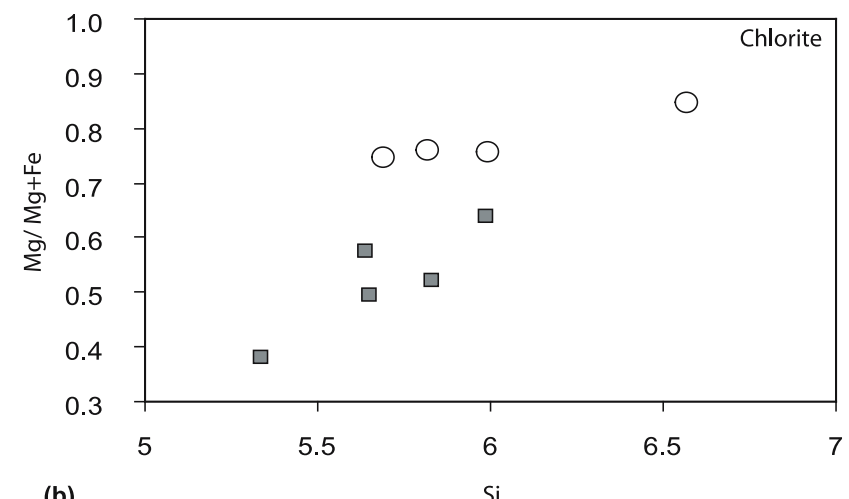

(b)

Figure 11. Representation of epidote and chlorite in binary diagrams. (a) $\mathrm{Al}$ vs. $\mathrm{Fe}^{3+}$. Filled squares epidote from MARK area (Gillis et al 1993), grey circles from SWIR (Stakes et al 1991) and open circles and black circles epidote from NCIR. Black circle represents vein epidote. (b) $\mathrm{Mg} / \mathrm{Mg}+\mathrm{Fe}$ vs. Si. Filled squares represent chlorite from MARK area (Gillis et al 1993) and open circles are chlorite from NCIR, respectively.

zones, oceanic rocks commonly have a tendency to gain $\mathrm{Na}$ and $\mathrm{Mg}$, and loss of $\mathrm{Ca}$ (Alt et al 1986; Harper et al 1988; Lecuyer et al 1990). In contrast, oceanic rocks in discharge zones, however are commonly epidotized, and show a gain of $\mathrm{Ca}, \pm \mathrm{Fe}, \pm \mathrm{Al}$ and loss of $\mathrm{Mg}$ (Harper et al 1988; Nehlig et al 1994). The abundance of albite with close association of chlorite especially within the altered gabbro from corner high (figure $3 \mathrm{~b}, \mathrm{f}$ ) suggests interaction of present gabbro with fluids enriched in $\mathrm{Na} / \mathrm{Mg}$ at $300^{\circ} \mathrm{C}$ temperature under greenschist facies condition (Seyfried et al 1978). Continuous supply of a Mg-depleted, Si-rich fluid, high in $\mathrm{Na} / \mathrm{Ca}$ molal ratio, enhances the albitisation processes $(\mathrm{Ab}$ content reaches up to $96 \mathrm{wt} \%)$ of the primary mineralogy. Such a condition generally prevails where Si-rich, Mg-free and Ca-depleted fluids which form during high temperature processes at depth are cooled both adiabatically and conductively during ascent (Von Damn et al 1985). Reaction of these fluids with fresh or previously altered basalt or gabbros are likely to be responsible for extensive albitisation. Seyfried et al (1978) and Seewald (1987) inferred that the removal of $\mathrm{Mg}$ from sea water at the pillow exterior (owing to chlorite formation) may provide high $\mathrm{Na} / \mathrm{Mg}$ ratio fluids for pillow-core alteration and albitisation. Mineralogy of present altered gabbro also exhibits similar kind of fluid interaction to cause pervasive albitisation once they have emplaced the sea bottom.

Clinopyroxene in mylonitic gabbro which crystallized from circulating hydrothermal fluid and also inherited the chemical signatures of fluid may be considered as secondary (table $4 \mathrm{~b}$ ). $\mathrm{MnO}$ enrichment (up to $0.64 \mathrm{wt} \%$ ) suggests that these veins are affected by circulation of hydrothermal fluids with evolving compositions (table 4b). Their iron enrichment trend also suggests that the fluids from where they crystallized must be iron-rich (figure 6). Also the difference in the temperature range for clinopyroxenes within the mylonite zone and outside of it suggests difference in their temperature of formation (figure 5). The progressive Fe-rich composition at late stage fluids is also exemplified by relatively high $\mathrm{Fe}$ concentration in vein epidote as compared to those replacing plagioclase (figure 11a).

In the absence of quartz, the temperature of amphibole-plagioclase equilibration may be quantified through the extent of $[\mathrm{NaSi}]_{-1}[\mathrm{CaAl}]$ exchange among the phase components (Holland and Blundy 1994):

$$
\begin{gathered}
\mathrm{NaCa}_{2} \mathrm{Mg}_{5} \mathrm{AlSi}_{\text {edenite }} \mathrm{O}_{22}(\mathrm{OH})_{22}+\underset{\text { albite }}{\mathrm{NaAlSi}_{3} \mathrm{O}_{8}} \\
=\mathrm{Na}_{2} \underset{\text { richterite }}{\mathrm{CaMg}_{5} \mathrm{Si}_{8} \mathrm{O}_{22}(\mathrm{OH})_{2}}+\underset{\text { anorthite }}{\mathrm{CaAl}_{2} \mathrm{Si}_{2} \mathrm{O}_{8}}
\end{gathered}
$$

They used nonlinear least squares regression and a well constrained plagioclase solid solution model to derive within site and cross site parameters for amphibole solid solutions. This allows the calculation of temperature for a particular amphibole and plagioclase composition. Calculated temperatures for present coexisting amphibole and plagioclase pair varies from $796^{\circ}$ to $825^{\circ} \mathrm{C}$ which certainly fall under high temperature metamorphism in ocean floor setting. More analyses of coexisting plagioclase-amphibole pairs are required to assess the accuracy of calculated temperatures. It can be concluded that the metamorphism of off-axis gabbro (mylonite gabbro) of the present study may have started about $700^{\circ}-800^{\circ} \mathrm{C}$. Typical mineral assemblages include plagioclase, Fe-Ti oxide, green and brown amphibole. These amphibole gneisses are texturally and mineralogically similar to dredged samples from Vema fracture zone (Honnorez et al 1984) and the Mid-Cayman rise (Ito and Anderson 1983). Comparison with amphibole chemistry with other 
Table 7. Representative analyses of chlorite. Total iron calculated as $\mathrm{Fe} \mathrm{O}_{\mathrm{t}}$.

\begin{tabular}{lcccr}
\hline Sample no. & DR-02-1 & DR-02-2 & DR-02-3 & DR-02-4 \\
\hline Oxides (wt\%) & & & & \\
$\mathrm{SiO}_{2}$ & 33.06 & 29.41 & 28.18 & 28.79 \\
$\mathrm{TiO}_{2}$ & 0.03 & n.d. & 0.04 & 0.01 \\
$\mathrm{Al}_{2} \mathrm{O}_{3}$ & 15.92 & 17.37 & 19.93 & 19.40 \\
$\mathrm{Cr}_{2} \mathrm{O}_{3}$ & 0.04 & 0.02 & n.d. & 0.02 \\
$\mathrm{FeO}_{\mathrm{t}}$ & 8.36 & 13.83 & 14.32 & 13.39 \\
$\mathrm{MnO}$ & 0.27 & 0.18 & 0.19 & 0.29 \\
$\mathrm{MgO}$ & 25.84 & 24.19 & 23.34 & 23.51 \\
$\mathrm{CaO}$ & 0.67 & 0.10 & 0.05 & 0.08 \\
$\mathrm{Na} 2 \mathrm{O}$ & 0.12 & 0.01 & 0.02 & 0.01 \\
$\mathrm{~K} 2 \mathrm{O}$ & 0.07 & 0.01 & 0.00 & 0.03 \\
$\mathrm{NiO}$ & 0.00 & 0.12 & 0.04 & n.d. \\
$\mathrm{Cl}$ & 0.06 & n.d. & n.d. & n.d. \\
$\mathrm{P}_{2} \mathrm{O}_{5}$ & $n . \mathrm{d}$. & 0.03 & 0.02 & 0.04 \\
$\mathrm{Total}$ & 84.42 & 85.27 & 86.13 & 85.57 \\
$\mathrm{Cations}$ based on 28 oxygens & & & \\
$\mathrm{Si}$ & 6.567 & 5.993 & 5.69 & 5.819 \\
$\mathrm{Ti}$ & 0.004 & n.d. & 0.006 & 0.002 \\
$\mathrm{Al}$ & 3.728 & 4.17 & 4.744 & 4.622 \\
$\mathrm{Cr}$ & 0.007 & 0.003 & n.d. & 0.004 \\
$\mathrm{Fe}$ & 1.388 & 2.356 & 2.419 & 2.263 \\
$\mathrm{Mn}$ & 0.046 & 0.03 & 0.033 & 0.05 \\
$\mathrm{Mg}$ & 7.649 & 7.343 & 7.024 & 7.082 \\
$\mathrm{Ca}$ & 0.142 & 0.023 & 0.01 & 0.017 \\
$\mathrm{Na}$ & 0.045 & 0.004 & 0.008 & 0.005 \\
$\mathrm{~K}$ & 0.017 & 0.002 & n.d. & 0.008 \\
$\mathrm{Catsum}$ & 19.593 & 19.924 & 19.934 & 19.872 \\
$\mathrm{X}$ & 0.85 & 0.76 & 0.74 & 0.76 \\
\hline & & & &
\end{tabular}

known occurrences of oceanic gabbro has shown that amphibole from mylonite gabbro is similar in composition with high temperature gabbro from Hole 735B, SWIR (figure 7, Stakes et al 1991). Ti and $\mathrm{Al}^{\mathrm{IV}}$ content of present amphibole (from mylonite gabbro) is comparatively high from amphibole of Mathematician Gabbro (figure 7, Stakes and Vanko 1986). However, amphibole from altered gabbro is compositionally similar with low temperature gabbro of SWIR as well as gabbro from Mathematician Ridge (figure 7).

\subsection{Geodynamic implications}

Metamorphosed mylonitic gabbroic rocks from the off-axis high, north of Vityaz TF setting record high temperature deformation metamorphism and recrystallisation. Fractures and microfractures in the gabbroic rocks that are filled with lower amphibolite to greenschist facies mineral assemblages suggest that the plutonic sequence has undergone brittle deformation during progressive cooling throughout the subsolidus regime, following the high temperature plastic deformation.
The abundance of amphibole in the zones of crystal-plastic deformation indicates these zones acted as the major conduits for hydrothermal fluids (figure 2, sample no. DR 01). Strong foliations as shown by amphiboles suggest stress during recrystallisation. The nearly homogeneous amphibole compositions from pargasite to actinolite in altered gabbro reflect progressive unroofing in the footwall of a brittle-ductile normal fault. The active detachment surface of the Vityaz megamullion facilitates the extension across an amagmatic spreading segment triggered the formation of altered gabbro (Drolia and DeMets 2005). Detachment faulting associated with crystal-plastic deformation at off axis high location would have thinned the crust and allowed the penetration of sea water.

The formation of amphibole veins in selective samples and alteration of clinopyroxene rim by amphibole in other samples suggest that the crystal-plastic deformation might be localised. Offaxis high set up, adjacent to Vityaz TF, as well as the presence of Vityaz megamullion probably represent extensional fault domains where 
lithospheric stretching of the lower crust occurred via brittle-ductile deformation (Karson and Dick 1983; Mevel et al 1991). Presence of Vityaz $\mathrm{TF}$, however, facilitates intense shearing helped to develop immense stress made the rock foliated during recrystallisation. Gabbros from corner high set up had solidified and cooled and subsequently fractured which facilitate to get the access of deep penetration of sea water, finally led to become metamorphosed. Rapid cooling due to the presence of Vityaz $\mathrm{TF}$ regulates the temperature of metamorphism and restricts the grade of metamorphism up to greenschist facies (figure 3, sample no. DR 02). The mineralogical assemblages further suggest declining fluid temperature of hydrothermal veins.

\section{Conclusion}

The present study confirms that the gabbros from NCIR record both the high temperature metamorphism and low temperature hydrothermal alteration in a segment of lower crust formed at a slow spreading ridge. The amphibole in mylonite gabbro is closely related with plastic deformation and its mineral chemistry suggests that they have formed at about $800^{\circ} \mathrm{C}$. The result of present study on mylonite gabbros thus provide a typical high temperature amphibolite facies assemblage of calcic plagioclase and hornblende. Based on their textural relations, we infer that the monomineralic amphibole veins from off-axis formed essentially at deep crustal level prior to its emplacement at present level which is common everywhere in the ocean basins (Phipps Morgan and Chen 1993). The temperature estimates for the amphibole veins in the present study are comparatively high as reported by Manning et al (1999) for amphibole + plagioclase veins in gabbros from Hess Deep $\left(687^{\circ}-745^{\circ} \mathrm{C}\right)$.

Altered gabbros from corner high adjacent to Vityaz TF formed exclusively under greenschist facies condition $\left(300^{\circ} \mathrm{C}\right)$, resulted the formation of greenschist mineralogical assemblages. Occurrences of actinolitic hornblende suggest locally the temperature had attained up to $450^{\circ} \mathrm{C}$. Evidences of decreasing fluid temperatures as indicated by precipitation of albite, chlorite and deposition of late-stage quartz veins/mosaic in the groundmass. Present study also suggests that low temperature alteration probably occurred once gabbro tectonically emplaced to the sea bottom. Progressive Feenrichment trend is also noticed in the late stage fluid.

The proactive role of tectonic activity (hence fault displacements and presence of megamullion) over magmatism in the present slow spreading
NCIR is well exemplified by the present finding of gabbroic rocks and further enhanced by postcrystalline mineralogical and textural changes due to rigorous hydrothermal circulation. Presence of the major detachment fault (hence Vityaz megamullion), which had a long deformation history, unroofed the lower crust and presumably caused rapid cooling. Thus, detachment faulting played a major role not only in the tectonic evolution of this crustal segment of NCIR but also in the timing and extent of alteration of the present lower ocean crust. We further conclude that deformation is necessary at present off-axis environment for prolonged alteration of ocean crust at slow spreading environment.

\section{Acknowledgements}

We thank Directors of NIO and NCAOR for their encouragements. Authors are also thankful to the Department of Ocean Development (now Ministry of Earth Sciences, Govt. of India) and CSIR Network Programme on Indian Ocean Ridges. We appreciate the help extended by the Captain and crew members onboard ORV Sagar Kanya and other colleagues during the sampling operations. Critical reviews by two anonymous reviewers helped to improve the manuscript. D R gratefully acknowledges to CSIR for Senior Research Fellowship and French Embassy in India for providing 'Sandwich PhD' fellowship during his stay at IPG-Paris, France.

\section{References}

Alt J C, Honnorez J, Laverne C and Emmermann R 1986 Hydrothermal alteration of a $1 \mathrm{~km}$ section through the upper oceanic crust, Deep Sea Drilling Project hole 504B: Mineralogy, chemistry, and evolution of seawater-basalt interactions; J. Geophys. Res. 91 10,309-10,355.

Alt J C and Bach W 2001 Data Report: low-grade hydrothermal alteration of uplifted lower oceanic crust, Hole 735B: Mineralogy and Isotope Geochemistry; In: Proceedings of the Ocean Drilling Program, Scientific Results 176 (eds) Natland J H, Dick H J B, Miller D J and Von Herzen R P (College Station, Texas), 1-24.

Batiza R and Vanko D S 1985 Petrographic evolution of large failed rifts in the Eastern Pacific: Petrology of volcanic and plutonic rocks from the Mathematician Ridge area and the Guadelupe Trough; J. Petrol. 26 $564-602$.

Baturin G N and Rozanova T V 1975 Ore mineralization in the rift zones of the Indian Ocean. Rift Zones of the World Ocean (eds) Vinogradov A P and Udinstev G B (John Wiley: New York) 431 pp.

Bird D K, Rogers R D and Manning C E 1986 Mineralized fracture systems of the Skaergaard Intrusion, East Greenland; Meddelelser om Gronland Geosci. 16 1-68.

Blundy J D and Holland T J B 1990 Calcic amphibole equilibria and a new amphibole-plagioclase geothermometer; Contrib. Mineral. Petrol. 104 208-224. 
Deer W A, Howie R A and Zussman I 1992 An introduction to rock-forming minerals, 2nd edn. (Longman: London) 696pp.

DeMets C, Gordon R G and Royer J Y 2005 Motion between the Indian, Capricorn, and Somalian plates since $20 \mathrm{Ma}$ : Implications for the timing and magnitude of distributed lithospheric deformation in the equatorial Indian Ocean; Geophys J. Int. 161 445-468.

Drolia R K and DeMets C 2005 Deformation in the diffuse India-Capricorn-Somalia triple junction from a multibeam and magnetic survey of the northern Central Indian ridge, $3^{\circ} \mathrm{S}-10^{\circ} \mathrm{S} ;$ Geochem. Geophys. Geosyst. 6 doi: $10.1029 / 2005 \mathrm{GC} 000950$.

Engel C G and Fisher R L 1975 Granitic to ultramafic rock complexes of the Indian Ocean ridge system, western Indian Ocean; Bull. Geol. Soc. Am. 82 $553-562$.

Gillis K M 1996 Trace element constraints on the origin of amphibole in gabbroic rocks from ODP site 894, Hess deep; In: Proceedings of Ocean Drilling Programme Scientific Results (eds) Mevel C, Gillis K M, Allan J F and Meyer P S (College Staion, Texas) 147 59-75.

Gillis K M, Thompson G and Kelley D S 1993 A view of the lower crustal component of hydrothermal systems at the Mid-Atlantic Ridge; J. Geophys. Res. 98 19,597-19,619.

Harper G D, Bowman J R and Kuhns R 1988 A field, chemical, and stable isotope study of subseafloor metamorphism of the Josephine ophiolite, California-Oregon; J. Geophys. Res. 93 4625-4656.

Holland T J B and Blundy J D 1994 Non-ideal interactions in calcic amphiboles and their bearing on amphiboleplagioclase thermometry; Contrib. Mineral. Petrol. 116 433-447.

Honnorez J, Mevel C and Montigny R 1984 Geotectonic significance of gneissic amphibolites from the Vema fracture zone, equatorial Mid-Atlantic Ridge; J. Geophys. Res. 89 $11,379-11,400$.

Ito E and Anderson AT Jr 1983 Submarine metamorphism of gabbros from the Mid-Cayman Rise: Petrographic and mineral constraints on hydrothermal processes at slow spreading ridges; Contrib. Mineral. Petrol. 82 $371-388$.

Ito E and Clayton R N 1983 Submarine metamorphism of gabbros from the Mid-Cayman Rise: An oxygen isotopic study; Geochim. Cosmochim. Acta 47 535-546.

Kagiamanidou M 1986 Etude geochemique des elements en traces les gabbros oceaniques an cours de leurs transformations metamorphiques; These doc, Univ. Piere et Marie Curie, Paris.

Karson J A and Dick H J B 1983 Tectonics of ridgetransform intersections at the Kane Frature Zone, MidAtlantic Ridge; Mar. Geophys. Res. 6 51-98.

Kelley D S and Delaney J R 1987 Two-phase separation and fracturing in mid-ocean ridge gabbros at temperatures greater than $700^{\circ} \mathrm{C}$; Earth Planet. Sci. Lett. 83 $53-66$.

Lecuyer C, Bouxel M and Albarede F 1990 Elemental fluxes during hydrothermal alteration of Trinity ophiolite (California, USA) by seawater; Chem. Geol. 89 87-115.

Lecuyer C and Reynard B 1996 High temperature alteration of oceanic gabbros by seawater (Hess Deep, Ocean Drilling Program Leg 147): Evidence from oxygen isotopes and elemental fluxes; J. Geophys. Res. 101 $15,883-15,897$.

Liou J G, Kim H S and Maruyama S 1974 Experimental studies of the phase relations between greenschist and amphibolite in a basaltic system; Am. J. Sci. 274 613-632.
Manning C E, Weston P E and Mahon K I 1999 Rapid high temperature metamorphism of East Pacific Rise gabbros from Hess Deep; Earth Planet. Sci. Lett. 144 123-132.

Marion E, Mevel C and Cannat M 1991 Evolution of oceanic gabbros from the MARK/Kane fracture intersection massif; Terra Abstr. 3310.

Mevel C 1984 Le metamorphisme dans la croute oceanique: apport de la petrologie a la comprehension des phenomenes de circulation hydrothernale et de deformation; These d'Etat, Universite P. et M.Curie, 434pp.

Mevel C 1987 Evolution of oceanic gabbros from DSDP Leg 82: Influence of the fluid phase on metamorphic crystallizations; Earth Planet. Sci. Lett. 83 67-79.

Mevel C 1988 Metamorphism of ocean layer 3, Gorringe Bank, eastern Atlantic; Contrib. Mineral. Petrol. 100 495-509.

Mevel C and Stamoudi C 1996 Hydrothermal alteration of the upper mantle section at Hess deep; In: Proceedings of Ocean Drilling Programme Scientific Results (eds) Mevel C, Gillis K M, Allan J F and Meyer P S (College Staion, Texas) 147 293-309.

Mevel C, Cannat M, Gente P, Marion E, Auzende J M and Karson J A 1991 Emplacement of deep crustal and mantle rocks on the west median valley wall of the MARK area (MAR, $\left.23^{\circ} \mathrm{N}\right)$; Tectonophys. $19031-53$.

Miyashiro A and Shido F 1980 Differentiation of gabbros in the Mid Atlantic Ridges near $24^{\circ} \mathrm{N}$; Geochem. J. 14 $145-154$.

Moody J B, Meyer D and Jenkins J E 1983 Experimental characterization of the greenschist/amphiboleite boundary in mafic systems; Am. J. Sci. 283 48-92.

Nehlig P, Juteau T, Bendel V and Cotton J 1994 The root zone of oceanic hydrothermal systems: Constraints from the Samail ophiolite (Oman); J. Geophys. Res. 99 4703-4713.

Phipps Morgan J and Chen Y J 1993 The genesis of oceanic crust: Magma injection, hydrothermal circulation, and crustal flow; J. Geophys. Res. 98 6283-6298.

Seewald J S $1987 \mathrm{Na}$ and Ca metasomatism during Hydrothermal Basalt Alteration: An experimental and theoretical study; M.Sc. thesis, University of Minnesota, Minnepolis, Minnesota.

Seyfried W E, Mottl M J and Bischoff J L 1978 Seawater/basalt ratio effects on the chemistry and mineralogy of spilites from the ocean floor; Nature $\mathbf{2 7 5}$ $211-213$.

Seyfried W E Jr, Berndt M E and Seewald J S 1988 Hydrothermal alteration processes at mid ocean ridges: Constraints from diabase alteration experiments, hot spring fluids and composition of the ocean crust; In: Seafloor Hydrothermal Mineralisation, Mineralogical Association of Canada (Nepean, Ontario) 787-804.

Spear F S 1981 An experimental study of hornblende stability and compositional variability in amphibolite; $\mathrm{Am}$. J. Sci. $281697-734$.

Stakes D and Vanko D A 1986 Multistage hydrothermal alteration of gabbroic rocks from the failed Mathematician Ridge; Earth Planet Sci. Lett. 79 75-92.

Stakes D, Mevel C, Cannat M and Chaupat T 1991 Metamorphic stratigraphy of Hole 735B; In: Proceedings of Ocean Drilling Programme Scientific Results (eds) Von Herzen R P and Robinson P T (College Station, Texas) $118153-180$.

Tartarotti P, Cannat M and Mevel C 1995 Gabbroic dikelets in serpentinised peridotites from the Mid-Atlantic Ridge at $23^{\circ} 20^{\prime} \mathrm{N}$; In: Mantle and lower crust exposed in oceanic ridges and in ophiolites (eds) Vissors R L M and Nicolas A (Dordrecht: Kluwer) 35-69. 
Vanko D A 1986 High chlorine amphiboles from oceanic rocks: Product of highly saline hydrothermal fluids? $\mathrm{Am}$. Mineral. 71 51-59.

Vanko D A and Stakes D S 1991 Fluids in oceanic layer 3: Evidence from veined rocks, Hole 735B, Southwest Indian Ridge; In: Proceedings of Ocean Drilling Programme Scientific Results (eds) Von Herzen R P and Robinson $\mathrm{P} \mathrm{T}$ et al (College Station, Texas) 181-215.
Von Damn K L, Edmond J M, Grant B, Measures C I, Walden B and Weiss R F 1985 Chemistry of submarine hydrothermal solutions at $21^{\circ} \mathrm{N}$, East Pacific Rise; Geochim. Cosmochim. Acta 49 11,334-11,346.

Zierenberg R A, Shanks W C III, Seyfried W E Jr, Koski R A and Strickler M D 1988 Mineralisation, alteration and hydrothermal metamorphism of the ophiolite hosted Turner-Albright sulfide deposits, southwestern Oregon; J. Geophys. Res. 93 4657-4675. 